\title{
Fen Bilgisi Öğretmen Adaylarının Isı-Sıcaklık ve Maddenin Halleri Konularına İlişkin Kavram Yanılgıları Arasındaki İlişkinin İncelenmesi ${ }^{1}$
}

\author{
DOI: $10.26466 /$ opus. 868034
}

\author{
Evrim Ural* - Ayșe Rabia Başaran Uğur ** \\ * Doç. Dr., Kahramanmaraş Sütçü İmam Üniversitesi Eğitim Fakültesi, Kahramanmaraş/Türkiye \\ E-Posta: evrimural@gmail.com \\ ORCID: 0000-0002-5427-2023 \\ ** Dr. Öğr., Erciyes Üniversitesi Eğitim Fakültesi, Kayseri/Türkiye \\ E-Posta: rabiabasaran1@hotmail.com \\ ORCID: $\underline{0000-0003-4654-7493}$
}

\section{Öz}

Bu çalışmanın amacı, fen bilgisi öğretmen adaylarının "Ist-Sıcaklık" ve "Maddenin Halleri" konularına ilişkin kavram yanılgıları arasındaki ilişkinin incelenmesidir. Bu çalışmada nitel araştırma desenlerinden biri olan fenomenoloji deseni kullanılmıştır. Çalışma grubunun seçiminde amaçlı örnekleme yöntemleri içerisinde yer alan ölçüt örneklemesi tercih edilmiştir. Araştırmanın çalı̧̧ma grubunu 2017-2018 eğitim öğretim yılı bahar döneminde, Akdeniz bölgesinde yer alan bir devlet üniversitesinin eğitim fakültesinde fen bilgisi öğretmenliği programında öğrenim gören 68 fen bilgisi öğretmen adayı oluşturmaktadır. Veri toplama aracı olarak araştırmacılar tarafından alanyazın incelemesi sonucunda hazırlanan "Isı-Sıcaklık Kavram Testi" ve "Maddenin Halleri Kavram Testi" kullanılmıştır. Verilerin analizinde ise betimsel, içerik ve sayısal analiz kullanılmışıı. Verilerin analizi sonucunda, öğretmen adaylarının "Maddenin Halleri" ve "Ist-Sıcaklık" konularına ilişkin kavram yanılgılarının olduğu tespit edilmiştir. Fen bilgisi öğretmen adaylarının ısıyı "enerji dönüşümü", sıcaklığı ise "stcaklı̆̆ın ya da soğukluğun göstergesi" şeklinde tanımladıkları belirlenmiştir. Ayrıca erime-buharlaşma-süblimleşme kavramlarına ilişkin en fazla ortaya çıkan kavram yanılgısının "sıcaklık artar", donma-yoğunlaşma-kıră̆ılaşma kavramlarına yönelik ise en fazla ortaya çıkan kavram yanılgısının "sıcaklık azalır" olduğu tespit edilmiştir. Öğretmen adaylarının ısı transferi, ısının akış yönü, ısı ve sıcaklığın maddenin hal değişim olayındaki rolüne yönelik bilgilerinde bilimsel olarak yanlışlıklar olduğu belirlenmiştir. Ayrıca öğretmen adaylarının günlük yaşam örneklerinde ısı-sıcaklık ve maddenin halleri konularını birbiriyle ilişkilendiremedikleri belirlenmiştir.

Anahtar Kelimeler: fen bilgisi öğretmen adayları, ısı ve sıcaklık, maddenin halleri, kavram yanılgısı, kavram yanılgıları arasındaki ilişki.

\footnotetext{
${ }^{1}$ Bu çalışma "Fen Bilgisi ve Sınıf Öğretmeni Adaylarının Maddenin Halleri ve Isı-Sıcaklık Konularındaki Kavram Yanılgılarının Incelenmesi" adlı tezin makalesidir.
}

OPUS @ C Uluslararası Toplum Araştırmaları Dergisi-International Journal of Society Researches ISSN:2528-9527 E-ISSN : 2528-9535

http://opusjournal.net 


\title{
An Analysis of the Relationship between Pre-service ScienceTeachers' Misconceptions Regarding Heat- Temperatureand Stateof Matter
}

\begin{abstract}
This study aimed to investigate the relationship between pre-service science teachers' misconceptions about "Heat-Temperature" and "States of Matter." Phenomenology, one of the qualitative research designs, was used in the study. The sample of the study was chosed through "criterion sampling" method, which was a non-random method of purposive sampling. The study group of the study was 68 preservice science teachers studying in the science teaching program at the faculty of education in a government university in the spring semester of the 2017-2018 academic year. "Heat and Temperature Concept Test" and "States of Matter Concept Test" were used as data collection tools. There searcher sprepared the data collection tools through out the literatu research. Descriptive, content, and frequency analysis were used in the analysis of the data. Data analysis displayed that pre-service science teachers' had misconceptions about "The States of Matter" and "Heat-Temperature." The findings displayed that the pre-service science teachers defined heat as "energy conversion" and temperature as "the indicator of warm thorcoldness". It was also determined that the most common misconception about the concepts of melting-evaporation-sublimationwas "temperatureincreases," and the most common misconception about the concepts of freezing-condensation-frosting was about "temperature decreases." It was determined that pre-service science teachers had misconceptions about heat transfer, the flow direction of heat, the role of heat and temperature in the change of the state of the matter. It was also determined that the pre-service science teachers' could not make connections between heat, temperature, and the state of matter subjects in daily life.
\end{abstract}

Keywords: Pre-service science teachers, heat and temperature, the states of matter, misconception, the relation between misconceptions. 


\section{Giriş}

"Maddenin Halleri" ve "Isı-Sıcaklık" konuları fen bilimlerinde temel teşkil eden katı, sıvı, gaz, erime, donma, buharlaşma, kaynama, yoğunlaşma, süblimleşme, kırağılaşma gibi birçok kavramı içerisinde barındırmaktadır. Değinilen kavramların anlaşılması, maddelerin yapısının ilerleyen konulardaki atom, termodinamik vb. konularının anlaşılmasına temel oluşturacaktır. Bu konular küçük yaşlardan itibaren bireylerin günlük yaşamda deneyimledikleri "çayın demlenmesi için suyun kaynaması ve bu kaynamanın olması için öncelikle ocağın çalıştırılarak ısının verilmesi gerektiği, kış aylarında arabaların camlarının buz tutması, buzluğa konulan suyun belli bir süre sonunda katı hale geçmesi, dışarıya çıkarılan buzun bir süre sonra sıvı haline geri dönmesi, eline kolonya döktügünde serinlik hissini hissetmesi, ağzı açlk bir kapta bekletilen suda, bir süre sonra azalmanın meydana gelmesi" gibi daha birçok olayla iç içe bir şekilde bulunmaktadır. Dolayısıyla bu durum isı-sıcaklık ve maddenin halleri konularının ayrılmaz bir yapıda olduğunu göstermektedir. Bir katının sıvı hale geçmesinin altında yatan temel nedenin, ısı ve sıcaklık konusu olduğunu kavramayan bir öğrencinin 1sı-sıcaklık ve maddenin halleri konuları arasında bağlantı kuramayacağını ve bu iki konuyu da anlamlı bir şekilde öğrenilemeyeceğini göstermektedir. Bu durum ise öğrencilerde konular arasında kavram yanılgılarının olacağını göstermektedir.

Fizik, kimya ve biyoloji eğitiminde gerçekleştirilen çalışmalar, verilen eğitime rağmen, eğitimin her kademesindeki bireylerde kavram yanılgilarının görüldüğünü ortaya koymaktadır (Alwan, 2011; Ayas, Coştu ve Karamustafaoğlu, 2002; Caleon ve Subramaniam, 2010; Saka ve Ayas, 2002; Ayvacı, Özsevgeç ve Cerrah, 2004). Dolayısıyla eğitimin her kademesinde gözlenen kavram yanılgılarının oluşumdaki en önemli etkenlerden biri öğretmenler olarak ifade edilmektedir (Asçı, Özkaya, Tekkaya, 2001). Kavram yanılgılarına sahip olan öğretmen adayları, mesleklerine başladıkları günden itibaren bunu fark edemeyecek ve öğrencilerin ders esnasında kendisinde bulunan kavram yanılgılarını alarak, zihinlerine yerleştirmelerine neden olacaktır. Kısacası öğretmenlerin konuya dair kavramlar arasındaki ilişkileri doğru bir şekilde kavramaları gerekmektedir. Isı-sıcaklık konusuna ilişkin var olan herhangi bir kavram yanılgısı, maddenin halleri konusuna geçildiğinde de ortaya çıkacak ve bu konunun da kavram yanılgilariyla anlatılmasına neden olacaktır. 
Öğretmen adaylarının mezun olmadan önce bu konulara dair kavram yanılgılarını göstererek, bu kavramların birbiri ile ilişkili olduğunu anlamaları gerekmektedir.

Alan-yazın incelediğinde "Madde, Maddenin Halleri" (Abraham, Williamson ve Westbrook, 1994; Boz, 2006; Çakır, 2005; Gürdal Kazancıŏglu, 2008; Griffths ve Preston, 1992; Kaplan, 2007; Othman, Treagust ve Chandrasegaron, 2007 ; Özalp, 2008; Sarıkaya, 2001; Sarı, 2014; Sopandi, Latip ve Sujana, 2017) ve "Isı-Sicaklık" (Alwan, 2011; Bayram, 2010; De Berg, 2008; Keser, 2007; Taşlıdere, Korur ve Eryılmaz, 2012) konularına ilişkin öğrenciler ile gerçekleştirilen kavram yanılgısı ile ilgili birçok çalışmanın yer aldığ 1 fakat geleceğin öğretmenleri olan öğretmen adayları ile yapılan "Isı Sıcaklık", "Maddenin Halleri" konularına yönelik çalışmaların ayrı ayrı gerçekleştirildiği ve sinırlı olduğu görülmektedir (Akgül, 2010; Demircioğlu, 2003; Erdem, Yılmaz ve Gücüm, 2004; Gönen ve Akgün, 2005; Ongun, 2006). Ayrıca yapılan alanyazın incelemesinde öğrencilerin ısı-sıcaklık ve maddenin halleri konularındaki kavram yanılgıların belirleyen (Sarı Ay, 2011) ve konuya ilişkin öğretmen adaylarının kavram yanılgılarını ortaya çıkaran, nitel desende ayrıntılı gerçekleştirilen çalışmaların sınırlı sayıda olduğu belirlenmiştir (Gökulu, 2015; Sopandi, vd., 2017). Fakat öğretmen adaylarının “Maddenin Halleri” ve "Isı-sıcaklık" konularında yer alan kavram yanılgıları arasındaki ilişkiyi inceleyen çalışmalara alanyazında rastlanmamıştır. Dolayısıyla, bu çalışmanın öğretmen adaylarının maddenin halleri, isı ve sıcaklık konusunda zihinlerinde yer alan kavram yanılgıları arasındaki ilişkinin belirlenmesi açısından önemli olduğu ve alan yazına katkı sağlayacağı düşünülmektedir.

\section{Çalışmanın Amacı}

Bu çalışmada fen bilgisi öğretmen adaylarının ısı-sıcaklık ve maddenin halleri konularına ilişkin kavram yanılgıları arasındaki ilişkinin incelenmesi amaçlanmıştır. Bu amaç doğrultusunda aşağıda yer alan soruya cevap aranmiştır.

Fen bilgisi öğretmen adaylarının 1sı-sıcaklık ve maddenin halleri konularına ilişkin kavram yanılgıları arasındaki ilişki nasıldır? 


\section{Yöntem}

\section{Çalışmanın Deseni}

Bu çalışmada nitel araştırma desenlerinden biri olan fenomenoloji deseni kullanılmıştır. Fenomenoloji deseni olgunun ya da kavramın altında yatan ortak anlamları keşfetmek için bireyler tarafından deneyimlenmiş dünyayı, tanımlamaya ve yaşanmış deneyimlerin özünü açklamaya çalışan bir desendir (Baker, Wuest ve Stern, 1992; Rose, Beeby ve Parker, 1995). Çalışmada fen bilgisi öğretmen adaylarının 1s1-sıcaklık ve maddenin halleri konularına ilişkin kavram yanılgıları arasındaki ilişkinin incelenmesi amaçlandığı için ve öğretmen adaylarının konuya ilişkin geçmiş yaşantıları söz konusu olduğu için bu desen tercih edilmiştir.

\section{Çalışma Grubu}

Fenomenoloji deseninde gerçekleştirilen araştırmalarda, olguyu açıklayacak kişilerin dikkatli bir şekilde seçilmesi ve olguyu yansıtabilecek olan birincil kişilerle çalışılması önemli bir husustur (Creswell, 2007; Patton, 2018). Bu nedenle çalışma grubu amaçlı örnekleme içerisinde yer alan ölçüt örnekleme kullanılarak belirlenmiştir. Amaçlı örnekleme, kavramların ve olguların açılanmasında önemli olan ve önceden belirlenmiş ölçüt ya da ölçütleri karşılayan durumlar üzerinde çalışmaya imkân tanıyan bir örnekleme türüdür (Merriam, 2013; Yıldırım ve Şimşek, 2013). Dolayısıyla, bu çalışmanın çalışma grubunu 2017-2018 eğitim-öğretim yılı bahar döneminde, bir devlet üniversitesinin eğitim fakültesinde fen bilgisi öğretmenliği programında üçüncü s1nıfta öğrenim gören 68 fen bilgisi öğretmen adayı oluşturmaktadır. Çalışma grubunun seçiminde ölçüt örneklemesinin tercih edilme nedeni ise öğrencilerin 1sı-sıcaklık ve maddenin halleri konularına ilişkin bilgileri kimya dersi kapsamında almış olmalarıdır.

\section{Veri Toplama Araçları}

Bu araştırmada veri toplama aracı olarak öğrencilerin kendilerini daha kolay ifade edebilmeleri için araştırmacılar tarafından uzman görüşü alınarak hazırlanan ve yazmaya dayalı olan "Isı-Sıcaklık Kavram Testi" ve "Maddenin 
Halleri Kavram Testi" kullanılmıştır. Kavram yanılgılarını belirlemek için görmeye dayalı, konuşmaya dayalı ve yazmaya dayalı raporlar kullanılmaktadır (Osborne ve Gilbert, 1980).Bu bağlamda veri toplama aracı, öğrencilerin görüşlerini alma, düşüncelerinin nasıl ve ne gibi durumlarda değişim gösterebileceği hakkında, araştırmacıya daha ayrıntılı bir şekilde bilgi edinme olanağı sağlayacaktır (Seidman, 2006).

Veri toplama aracı hazırlanırken araştırmacılar tarafından alanyazın taraması gerçekleştirilmiş ve çalışmanın konusu ile ilgili nicel ve nitel çalışmalar incelenmiştir. "Isı Sıcaklık Kavram Testi" oluşturulurken 2. soru Şendur (2004); 3. soru Sarı Ay (2011); 4. soru Bayrakçı (2007); 5. Soru Gürdal Kazancıŏlu (2008) çalışmaları göz önüne alınarak hazırlanmıştır. 1. soru ise araştırmacılar tarafından hazırlanmıştır. "Maddenin Halleri Kavram testi" hazırlanırken ise 1. soru ve 2. soru Demircioğlu (2003) ve Osborne ve Cosgrove (1983); 3. soru Hacımustafaoğlu (2015); 4. soru Kızılaslan'ın (2016) gerçekleştirdikleri çalışmalar göz önüne alınarak hazırlanmıştır. Hazırlanan veri toplama aracının ilk hali incelenmesi için Fen Bilgisi Eğitimi Anabilim Dalı'nda görev yapan uzmanlara verilmiştir. Uzmanlardan gelen dönütler doğrultusunda gerekli düzenlemeler yapılarak "Isı-Sıcaklık Kavram Testi" ve "Maddenin Halleri Kavram Testi" nin son hali hazırlanmıştır. Isı ve sıcaklık kavram testinde yer alan sorular, ısı ve sıcaklık tanımlarını bilimsel olarak ortaya koymayı, ısı alışverişi sonucu hal değişiminin nasıl gerçekleştiği ve bu değişim sonucunda ortamda ne gibi değişikliklerin olacağı, erime sıcaklıkları bilinen maddelerin donma sıcaklıkları ve maddelerin erime durumuna yönelik açıklamalar yapabilmeyi amaçlamaktadır. Maddenin halleri kavram testinde yer alan sorular ise, hal değişim grafiğini yorumlayabilme, hal değişimi sırasında meydana gelen değişimleri ortaya koyabilme, günlük hayatta karşılaştığımız bazı durumlarla hal değişimini ilişkilendirme ve hal değişiminin ısı ve sıcaklıkla ilişkisini ortaya çıkarmayı amaçlamaktadır. "Isı-Sıcaklık Kavram Testi" ve "Maddenin Halleri Kavram Testi" Ek-1 ve Ek-2 olarak sunulmuştur.

\section{VerilerinToplanmasi}

Verilerin toplanmasından önce çalışmanın yapılacağı eğitim fakültesinden gerekli izinler alınmıştır. Daha sonra çalışmaya katılan gönüllü öğretmen adayları belirlenmiş ve çalışmanın amacından ve öneminden bahsedilmiştir. 
Bu doğrultuda çalışmaya katılan gönüllü fen bilgisi öğretmen adayları ile verilerin toplanması için bir program yapılmış ve veriler 2017-2018 eğitim-öğretim yılı bahar döneminde toplanmıştır. Uygulama başlamadan önce öğretmen adaylarına "Maddenin Halleri Kavram Testi" ve "Isı-Sicaklık Kavram Testi" formunda yer alan soruları samimi, doğru ve gerçek düşüncelerini ifade edecek bir şekilde cevaplamalarının, çalışmanın amacına ulaşması açısından önemli olduğu ifade edilmiştir. Öğretmen adaylarına veri toplama aracını doldurmaları için 30-45 dakika arası süre verilmiştir.

\section{Verilerin Analizi}

Verilerin analizinde betimsel, içerik ve sayısal analiz kullanılmıştır. Betimsel analiz, veri toplama teknikleriyle elde edilen verilerin daha önceden belirlenen temalara göre özetlenmesi ve yorumlanmasını içeren nitel bir veri analiz türüdür (Yıldırım ve Şimşek, 2013). Değinilen nitel analiz türünde asıl amaç, elde edilen verilerin okuyucuya özetlenmiş ve yorumlanmış şekli ile sunulmasıdır. İçerik analizi, temalar ya da kategoriler kapsamında verileri kodlar halinde bir araya getirerek, kodları okuyucunun anlayabileceği bir biçimde yorumlamaktır (Creswell, 2007; Yıldırım ve Şimşek, 2013). Çalışmada kavramlar arasındaki ilişkilerin derinlemesine incelenmesi amaçlanmasından dolayı içerik analizi tercih edilmiştir. Sayısal analiz ise nitel çalışmalarda, araştırmaya katılan kişilerin düşüncelerini sayısal olarak sembolize eden bir analiz çeşididir (Miles ve Huberman, 2015). Veriler bulgular şeklinde okuyucuya sunulduğunda, yüzde değerleri ile kolayca karşılaştırma yapabilmeleri için bu çalışmada sayısal analiz tercih edilmiştir. Veri analizi sürecinde araştırmacı tarafından, veri toplama aracında yer alan sorular soru sırasına göre tek tek okunmuş kavram yanılgisı olarak belirlenen kelime ya da kelimelerin altı çizilmiştir. Daha sonra elde edilen bu verilerden yola çıkılarak temalar belirlenmiştir. Örneğin ilk sırada yer alan “Isı ve sıcaklık kavramlarını açıklayınız." maddesinde kavram yanılgıları belirlenmiş ve bu doğrultuda "bilimsel olarak kabul edilen cevap", "kavram yanılgısı içeren cevap" şeklinde temalar oluşturulmuştur. Veriler analiz edildikten sonra bulgular şeklinde yazılmadan önce tablo halinde uzman görüşüne sunulmuş ve uzman dönütleri doğrultusunda yapılan düzenlemelerle analiz süreci sona ermiştir. 


\section{Geçerlik ve Güvenirlik}

Nitel araştırmalarda geçerlilik ve güvenirlik çalışmasının gerçekleştirilebilmesi için iç geçerlik, dış geçerlik, iç güvenirlik ve dış güvenirlik adımlarının incelenmesi gerekmektedir (Merriam, 2013). İç geçerlik uzun süreli etkileşim, uzman görüşü ve çeşitlemeyi içermektedir (Arastman, Öztürk Fidan ve Fidan, 2018). Çalışmada uzun süreli etkileşim için gönüllü öğretmen adaylarına çalışmanın amacı, önemi hakkında bilgiler verilmiştir. Veri toplama aracının son hali ise uzman görüşü doğrultusunda hazırlanmıştır. Çeşitleme aşamasında ise veri analizinde betimsel, içerik ve sayısal analiz birlikte kullanılarak veri analiz çeşitlemesi yapılmıştır. Dış geçerlik amaçlı örnekleme, ayrıntılı betimlemeyi içermektedir (Başkale, 2016). Bu doğrultuda çalışmada amaçlı örnekleme kullanılmıştır. Ayrıntılı betimleme de giriş, yöntem detaylı bir şekilde yazılmış, tartışma ve sonuç bölümünde ise bulgular alanyazın ile ilişkilendirilmiştir. İç güvenirlik bulguların var olduğu gibi okuyuculara sunulmasını, araştırmacı-uzman kodlama tutarlılı̆̆ını içermektedir (Başkale, 2016). Bu doğrultuda çalışmadan elde edilen bulgular yorum yapılmadan sunulmuş ve doğrudan alıntılara yer verilmiştir. Araştırmacı-uzman kodlama tutarlığı için araştırmacının belirlediği kavram yanılgıları uzmana gösterilmiş, uzman kontrolleri sonucunda, fikir birliğine ulaşılmıştır. Dış güvenirlik araştırma sonuçlarının verilerle karşılaştırılmasını içermektedir (Başkale, 2016). Çalışmanın dış güvenirliğini sağlamak için uzman kontrolüne gidilmiştir. Çalışmanın bulgular, tartışma ve sonuç bölümleri uzman görüşüne uygun olarak hazırlanmıştır.

\section{Bulgular}

Fen bilgisi öğretmen adaylarının 1sı ve sıcaklık kavram testinde yer alan "Isı kavramını açıklayınız" sorusuna yönelik bulgular aşağıda yer alan tabloda gösterilmektedir. 
Tablo 1. Fen bilgisi öğretmen adaylarının ısı kavramına ilişkin bulguları

\begin{tabular}{lll}
\hline Temalar & F & \% \\
\hline Bilimsel olarak kabul edilen cevap & 39 & 57,35 \\
Kavram yanılgısı içeren cevap & 29 & 42,65 \\
Cevap yok & - & - \\
Kavram yanılgıları & & \\
KY-1. Enerji dönüşümü & 7 & 24,10 \\
KY-2. Bir taneciğin kinetik enerjisi & 2 & 6,90 \\
KY-3. Ortalama kinetik enerji & 2 & 6,90 \\
KY-4. Fiziksel enerji & 2 & 6,90 \\
KY-5. Ortam geçişi & 1 & 3,45 \\
KY-6. Sıcaklık dengelenmesi & 1 & 3,45 \\
KY-7. Enerji alışverişi & 1 & 3,45 \\
KY-8. Barometre ile ölçülen değer & 1 & 3,45 \\
KY-9. Tanecik hareketi & 1 & 3,45 \\
KY-10. Maddenin tanecikli yapısı & 1 & 3,45 \\
KY-11. Maddeler arası etkileşim & 1 & 3,45 \\
KY-12. Enerji farkı & 1 & 3,45 \\
KY-13. Çevreye yayılan enerji & 1 & 3,45 \\
KY-14. İç enerji & 1 & 3,45 \\
KY-15. Kinetik enerji değişimi & 1 & 3,45 \\
KY-16. Potansiyel enerji & 1 & 3,45 \\
KY-17. Maddenin sıcaktan soğuğa doğru akışı & 1 & 3,45 \\
KY-18. Aktarılan enerji & 1 & 3,45 \\
KY-19. Değişmeyen madde miktarı & 1 & 3,45 \\
KY-20. Genel enerji & 1 & 3,45 \\
\hline
\end{tabular}

Yukarıdaki tabloda Fen bilgisi öğretmen adaylarının 1sı kavramına dair ifadeleri yer almaktadır. İfadeler incelendiğinde öğretmen adaylarının $\% 57,35$ 'i bilimsel olarak doğru cevap verirken, $\% 42,65$ ' inin cevaplarında kavram yanılgılarının olduğu görülmektedir. Tablo incelendiğinde Fen bilgisi öğretmen adaylarının 1sı kavramına dair en fazla ortaya çıkan kavram yanılgısının "enerji dönüşümü $(\% 24,10)$ " olduğu, diğer kavram yanılgılarının ise "bir taneciğin kinetik enerjisi $(\% 6,90)$, ortalama kinetik enerji $(\% 6,90)$ ve fiziksel enerji $(6,90)$ " olduğu görülmektedir. Birer öğrenci $(\% 3,45)$ ise 151 tanımını yaparken "genel enerji", "değişmeyen madde miktarı", "aktarlan enerji", "enerji farkı", "maddenin tanecikli yapısı", "barometre ile ölçülen değer" gibi kavram yanılgisı içeren ifadeler kullanmışlardır.

Fen bilgisi öğretmen adaylarının isı ve sıcaklık kavram testinde yer alan "Sıcaklık kavramını açıklayınız" sorusuna yönelik bulgular aşağıda yer alan tabloda gösterilmektedir. 
Tablo 2. Fen bilgisi öğretmen adaylarının sıcaklık kavramına ilişkin bulguları

\begin{tabular}{lll}
\hline Temalar & F & \% \\
\hline Bilimsel olarak kabul edilen cevap & 44 & 64,70 \\
Kavram yanılgısı içeren cevap & 21 & 30,88 \\
Cevap yok & 3 & 4,42 \\
Kavram yanılgıları & & \\
KY-1. Sıcaklığın ya da soğukluğun göstergesi & 10 & 47,64 \\
KY-2. Ilıklığı gösteren nicelik & 2 & 9,52 \\
KY-3. Soğukluğu ifade eden birim & 2 & 9,52 \\
KY-4. Alınan verilen enerji & 1 & 4,76 \\
KY-5. Kinetik enerji durumu & 1 & 4,76 \\
KY-6. Soğukluğu ya da llıklığın göstergesi & 1 & 4,76 \\
KY-7. Enerjinin depolanması & 1 & 4,76 \\
KY-8. Titreşim hareketi & 1 & 4,76 \\
KY-9. Toplam kinetik enerji & 1 & 4,76 \\
KY-10.Havanın sicak ya da soğuk olmasının ifadesi & 1 & 4,76 \\
\hline
\end{tabular}

Tablo2.'de fen bilgisi öğretmen adaylarının sıcaklık kavramına yönelik ifadeleri yer almaktadır. Tablo incelendiğinde öğrencilerin \%64,70'inin bilimsel olarak doğru tanımlama yaptığı, \%30,88'inin kavram yanılgılarının olduğu ve $\% 4,42$ 'sinin ise kavrama dair tanımlama yapamadığ görülmektedir. Sıcaklık kavramına dair en fazla ortaya çıan kavram yanılgısı "sıcaklı̆̆ı ya da soğukluğun göstergesi $(\% 47,64)$ " olduğu görülmektedir. Ayrıca öğrencilerin sıcaklığın tanımını yaparken "ılıklı̆̆ı gösteren nicelik $(\% 9,52)$ ve Soğukluğu ifade eden birim $(\% 9,52)$ " ifadelerini kullanmış ve kavram yanılgılarına sahip oldukları belirlenmiştir. Bireröğrencinin $(\% 4,76)$ ise sıcaklığı tanımını yaparken "alınan verilen enerji", "kinetik enerji durumu", "soğukluğu ya da ılıklğın göstergesi", "enerjinin depolanması", "titreşim hareketi", "havanin sıcak ya da soğuk olmasının ifadesi", "toplam kinetik enerji" ifadelerini kullandıkları görülmektedir.

Fen bilgisi öğretmen adaylarının ısı ve sıcaklık kavram testinde yer alan "Okuldaki koridorlar su ile yıkandıktan ya da paspasla silindikten sonra serinleme hissedilir. Bu serinleme hissi neden kaynaklanmaktadır?" sorusuna yönelik bulgular aşağıda yer alan tabloda gösterilmektedir. 
Tablo 3. Fen Bilgisi öğretmen adaylarnın serinleme hissine dair bulguları

\begin{tabular}{lll}
\hline Temalar & F & \% \\
\hline Bilimsel olarak kabul edilen cevap & 49 & 72,07 \\
Kavram yanılgısı içeren cevap & 15 & 25,05 \\
Cevap yok & 4 & 5,88 \\
Kavram yanılgıları & & \\
KY-1. Su serinliğini yere verir. & 2 & 13,33 \\
KY-2. Sudan koridora soğukluk geçer. & 2 & 13,33 \\
KY-3. Hava ile koridor arasında ısı alışverişi olur. & 2 & 13,33 \\
KY-4. Toz tanecikleri su ile temizlendiği için beton açı̆̆a çıkar ve serinleme olur. & 1 & 6,66 \\
KY-5. Isınan hava yükselir. Soğuk hava altta kalır ve serinleme hissi olur. & 1 & 6,66 \\
KY-6. Yerden havaya soğuk hava tanecikleri çıkar. & 1 & 6,66 \\
KY-7. Paspas ısıyı emer. & 1 & 6,66 \\
KY-8. Hava değişimi sayesinde sıcaklık azalır. & 1 & 6,66 \\
KY-9. Sıcaklık suya geçer. & 1 & 6,66 \\
KY-10. Sıcaklık alışverişi olur. & 1 & 6,66 \\
KY-11. Yükselen soğuk hava serinlik verir. & 1 & 6,66 \\
KY-12. Soğuk teması sıcaklığı azaltır. & 1 & 6,66 \\
\hline
\end{tabular}

Yukarıda yer alan tabloda öğrencilerin $\% 72,07$ 'si serinleme hissinin nedenini bilimsel açıdan doğru bir şekilde cevapladığı, \%5,88'inin ise konu hakkında fikirlerinin olmadığı görülmektedir. Fen bilgisi öğretmen adaylarının \%22,05'inin ise konuya dair kavram yanılgilarının olduğu belirlenmiştir. Öğretmen adaylarının frekans büyüklüklerine göre "Su serinliğini yere verir (\%13,33).", “Sudan koridora soğukluk geçer (\%13,33).", "Hava ile koridor arasinda ısı alşverişi olur (\%13,33).", "Toz tanecikleri su ile temizlendiği için beton açı̆̆a çıkar ve serinleme olur $(\% 6,66)$.", "Isman hava yükselir. Soğuk hava altta kalır ve serinleme hissi olur (\%6,66).", "Paspas ısıyı emer (\%6,66).", "Sıcaklık alışverişi olur $(\% 6,66)$ " şeklinde kavram yanılgılarının bulunduğu görülmektedir.

Fen bilgisi öğretmen adaylarının ısı ve sıcaklık kavram testinde yer alan "Avucumuza bir parça buz alıp beklediğimizde bir süre sonra buz parçasının eriyerek suya dönüştüğünü görürüz. Sizce bunun nedeni ne olabilir?" sorusuna verdikleri cevaplar aşağıda yer alan tabloda gösterilmektedir.

Tablo 4. Fen bilgisi öğretmen adaylarının buz parçasının erimesine dair bulguları

\begin{tabular}{|c|c|c|}
\hline Temalar & $\mathbf{F}$ & $\%$ \\
\hline Bilimsel olarak kabul edilen cevap & 59 & 86,76 \\
\hline Kavram yanılgısı içeren cevap & 9 & 13,24 \\
\hline Cevap yok & - & - \\
\hline \multicolumn{3}{|l|}{ Kavram yanılgiları } \\
\hline KY-1. Buz sicaklık kaybeder. & 2 & 22,22 \\
\hline KY-2. Sıcaklığın iletim yoluyla yayılmasından dolayı buz erir. & 2 & 22,22 \\
\hline KY-3. Buzdaki isı elimize geçer. & 2 & 22,22 \\
\hline KY-4. Buz hava ile temas ettiği için erir. & 1 & 11,11 \\
\hline KY-5. Elimizin sıcaklı̆ı buza geçer. & 1 & 11,11 \\
\hline KY-6. Sicaklık alışverişinden dolayı buz erir. & 1 & 11,11 \\
\hline
\end{tabular}


Tablo4.'te görüldüğü üzere fen bilgisi öğretmen adaylarının \%86,76'sının konuya dair bilimsel olarak doğru, \%13,24'ünün ise kavram yanılgısı içeren cevaplar verdikleri görülmektedir. Bu kavram yanılgiları "Buz sıcaklık kaybeder (\%22,22)", "Buzdaki ısı elimize geçer (\%22,22)", "Buz hava ile temas ettiği için erir $(\% 11,11)$ ", "Elimizin sıcaklı̆̆ı buza geçer $(\% 11,11)$ ", "Sıcaklık alışverişinden dolayı buz erir (\%11,11)" şeklindedir.

Fen bilgisi öğretmen adaylarının isı ve sıcaklık kavram testinde yer alan “Su $0^{\circ} \mathrm{C}^{\prime}$ de donarak buz haline geçer. Su donarken enerjisinin tamamını verdiğinden $0^{\circ} \mathrm{C}^{\prime}$ deki buzun 1 sısı yoktur. Bu ifadenin doğruluğu hakkında ne düşünüyorsunuz?" sorusuna verdikleri cevaplar aşağıda yer alan tabloda gösterilmektedir.

Tablo 5. Fen bilgisi öğretmen adaylarnın buzun ısısına yönelik bulguları

\begin{tabular}{lll}
\hline Temalar & $\mathbf{F}$ & $\mathbf{\%}$ \\
\hline Bilimsel olarak kabul edilen cevap & 28 & 41,18 \\
Kavram yanılgısı içeren cevap & 30 & 44,11 \\
Cevap yok & 10 & 14,71 \\
Kavram yanılgıları & & \\
KY-1. Su donarken ısısının tamamını verir. & 8 & 26,67 \\
KY-2. Sıcaklık 0 ${ }^{\circ}$ C olduğunda enerji olmadığı için ısısı olmaz. & 8 & 26,67 \\
KY-3. Sıfır başlangıç (nötr sıcaklık) olduğu için ısısı yoktur. & 5 & 16,69 \\
KY-4. +4 ${ }^{\circ} C^{\prime}$ de daha yoğun olduğu için ısısı yoktur. & 2 & 6,66 \\
KY-5. Isı eksi değer alabildiği için ısısı vardır. & 1 & 3,33 \\
KY-6. Buz ortama ısı vereceği için ısısının hepsini kaybeder. & 1 & 3,33 \\
KY-7. Isı hakkında yorum yapılamaz. & 1 & 3,33 \\
KY-8. Potansiyel enerjiden dolayı ısısı vardır. & 1 & 3,33 \\
KY-9. Isısının tamamını hal değişiminde kullandığı için ısısı yoktur. & 1 & 3,33 \\
KY-10. +4/-4 kuralından dolayı ısısı vardır. & 1 & 3,33 \\
KY-11. Sıcaklık ve soğukluk eşit olacağından dolayı, ısısı yoktur. & 1 & 3,33 \\
\hline
\end{tabular}

Yukarıda yer tabloya göre fen bilgisi öğretmen adaylarının \%41,18' inin bilimsel açıdan doğru, \%44,11'inin ise kavram yanılgısı içeren cevaplar verdiği görülmektedir. Öğretmen adaylarını \%14,71'i ise konuya ilişkin herhangi bir cevap vermedikleri belirtilmektedir. Tablo incelendiğinde öğrencilerde yer alan en fazla kavram yanilgilarının "Su donarken ısısının tamaminı verir $(\% 26,67)$. Sıcaklık $0{ }^{\circ} \mathrm{C}$ olduğunda enerji olmadı̆̆ı için ısısı olmaz (\%26,67)." İfadelerinin olduğu görülmektedir. Bununla birlikte öğretmen adaylarında ortaya çıkan diğer kavram yanılgıları ise frekans büyüklüklerine göre şu şekildedir: "Sıfir başlangıç (nötr sıcaklık) olduğu için ısısı yoktur (\%16,69).", " $+4{ }^{\circ} \mathrm{C}^{\prime}$ de daha yoğun olduğu için ısısı yoktur (\%6,66).", "Isı eksi değer alabildiği için ısısı vardır 
(\%3,33).", "Buz ortama ısı vereceği için ısısının hepsini kaybeder (\%3,33).", "Isı hakkında yorum yapılamaz (\%3,33).", "Isısının tamamını hal değişiminde kullandığı için ısısı yoktur (\%3,33).", "Potansiyel enerjiden dolayı ısısı vardır (\%3,33).", “+4/4 kuralından dolayı ısısı vardır (\%3,33).", "Sıcaklık ve soğukluk eşit olacağından dolayı, ısısı yoktur (\%3,33)."

Fen bilgisi öğretmen adaylarının 1sı ve sıcaklık kavram testinde yer alan "Grafikte naftalin, kükürt, bakır ve kurşunun erime sıcaklıkları verilmiştir. Hangi maddenin donma sicaklığı en yüksektir ve hangi maddeyi eritmek daha zordur?" sorusuna yönelik bulgular aşağıda yer alan tablo da gösterilmektedir.

Tablo 6. Fen bilgisi öğretmen adaylarının donma sıcaklığı ve erimenin zor olduğu maddeye yönelik bulgularn

\begin{tabular}{|c|c|c|}
\hline Donma Sıcaklığı İle İlgili Temalar & $\mathbf{F}$ & $\%$ \\
\hline Bilimsel olarak kabul edilen cevap & 40 & 58,82 \\
\hline Kavram yanılgısı içeren cevap & 26 & 38,24 \\
\hline Cevap yok & 2 & 2,94 \\
\hline \multicolumn{3}{|l|}{ Kavram yanılgıları } \\
\hline KY-1.Naftalinin erime noktası düşük olduğu için, donma sıcaklığı en yüksektir. & 25 & 96,15 \\
\hline KY-2. Kurşunda tanecik arası boşluk olmadığı için donma sıcaklığı en yüksektir. & 1 & 3,85 \\
\hline Eritmenin Zor Olduğu Madde İle İlgili Temalar & f & $\%$ \\
\hline Bilimsel olarak kabul edilen cevap & 60 & 88,24 \\
\hline Kavram yanılgısı içeren cevap & 8 & 11,76 \\
\hline Cevap yok & - & \\
\hline \multicolumn{3}{|l|}{ Kavram yanılgıları } \\
\hline KY-1. Naftalinin erime sıcaklığı düşük olduğu için, eritilmesi daha zordur. & 7 & 87,50 \\
\hline KY-2. Naftalin en soğuk madde olduğu için eritilmesi daha zordur. & 1 & 12,50 \\
\hline
\end{tabular}

Yukarıda yer alan tabloda donma sıcaklığı, eritmenin zor olduğu madde ile ilgili temalar yer almaktadır. Fen bilgisi öğretmen adaylarının \%58,82'si donma sıcaklığı ile ilgili doğru cevaplar verirken, \%38,24'ünün kavram yanılgısı içeren ifadeler kullandıkları görülmektedir. Öğretmen adaylarının $\% 2,94 ' u ̈$ ise konuya ilişkin bilgilerinin bulunmadığını ifade etmişlerdir. Donma sıcaklığına dair öğrencilerin kavram yanılgıları incelendiğinde, en fazla ortaya çıkan kavram yanılgısının "Naftalinin erime noktası düşük olduğu için, donma sıcaklı̆̆ en yüksektir (\%96,15)." olduğu görülmektedir. Ortaya çkan bir diğer kavram yanılgısı ise "Kurşunda tanecik arası boşluk olmadığı için donma sıcaklığı en yüksektir (\%3,85)." ifadesidir. Eritmenin zor olduğu maddeler temasında ise fen bilgisi öğretmen adaylarının \%88,24'ü bilimsel olarak doğru cevap verirken, \%11,76'sı kavram yanılgıları içeren cevaplar verdikleri 
görülmektedir. Tablo.6 incelendiğinde, en fazla ortaya çıkan kavram yanılg1sının "Naftalinin erime sıcaklığı düşük oldŭ̆u için, eritilmesi daha zordur $(87,50)$." olduğu belirlenmiştir. Bunun yanı sıra bir öğrencinin $(\% 12,50)$ ise konuya ilişkin "Naftalin en soğuk madde olduğu için eritilmesi daha zordur." şeklinde kavram yanılgısının olduğu belirlenmiştir.

Fen bilgisi öğretmen adaylarının maddenin helleri kavram testinde yer alan "Bu grafik ne olarakadlandırılır? I.-II.-III. bölgelerde ne gibi değişiklikler meydana gelir?"sorusuna yönelik bulguları aşağıda yer alan tabloda gösterilmektedir

Tablo 7. Fen bilgisi öğretmen adaylarnın hal değişim grafiğine verdikleri cevaplara ilişkin bulgularn

\begin{tabular}{lll}
\hline Grafiğin Adı İle İlgili Temalar & F & $\%$ \\
\hline Doğru adlandırma & 62 & 91,18 \\
Kavram yanılgısı içeren adlandırma & 2 & 2,94 \\
Cevap yok & 4 & 5,88 \\
Kavram yanılgıları & & \\
KY-1. Erime grafiği & 1 & 50,00 \\
KY-2. Isı zaman grafiği & 1 & 50,00 \\
Grafiğin I. Bölgesi İle İlgili Temalar & $\mathbf{F}$ & $\%$ \\
Bilimsel olarak kabul edilen cevap & 64 & 94,12 \\
Kavram yanılgısı içeren cevap & - & - \\
Cevap yok & 4 & 5,88 \\
Grafiğin II. Bölgesi İle İlgili Temalar & $\mathbf{F}$ & $\%$ \\
Bilimsel olarak kabul edilen cevap & 64 & 94,12 \\
Kavram yanılgısı içeren cevap & 1 & 1,47 \\
Cevap yok & 3 & 4,41 \\
Kavram yanılgıları & & \\
KY-1. Kaynama olayı meydana gelir. & 1 & 100,00 \\
Grafiğin III. Bölgesi İle İlgili Temalar & $\mathbf{F}$ \\
Bilimsel olarak kabul edilen cevap & 63 & $\%$ \\
Kavram yanılgısı içeren cevap & 1 & 92,65 \\
Cevap yok & 4 & 1,47 \\
Kavram yanılgıları & & 5,88 \\
KY-1. Yoğuşma meydana gelir. & 1 & 100,00 \\
\hline & & \\
\hline
\end{tabular}

Yukarıda yer alan tabloda görüldüğü üzere, fen bilgisi öğretmen adaylarını \%91,18'i grafiğin adlandırmasını doğru bir şekilde yaparken, \%2,94'ünün kavram yanılgısı içeren adlandırma yaptıkları belirlenmiştir. Kavram yanılgısına sahip öğrencilerin yarısı grafiği "erime grafiğ $i$ " şeklinde, diğer yarısı ise "ısı zaman" grafiği şeklinde adlandırmışlardır. Grafiğin birinci bölgesine dair temalar incelendiğinde ise öğretmen adaylarının hemen hemen hepsinin $(\% 94,12)$ doğru, \%5,88'inin ise soruya cevap vermedikleri gö- 
rülmektedir. Grafiğin ikinci bölgesine ait temalar incelendiğinde ise öğretmen adaylarının \%94,12'sinin doğru, \%1,47'sinin ise kavram yanılgisına sahip oldukları görülmektedir. Grafiğin ikinci bölgesine dair kavram yanılgısı şu şekildedir: "Kaynama olayı meydana gelir." Grafiğin üçüncü bölgesine ait temalar incelendiğinde ise fen bilgisi öğretmen adaylarının \%92,65'inin doğru, \%1,47'sinin ise kavram yanılgısının olduğu tespit edilmiştir. Tespit edilen bu kavram yanılgısının "Yoğuşma meydana gelir." şeklinde olduğu görülmektedir.

Fen bilgisi öğretmen adaylarının maddenin halleri kavram testinde yer alan "Eve geldiğinizde içeceğin soğuması için kısa bir süre buzluğa içeceği koydunuz. Buzluktan alıp içmeye başladınız. Bir süre sonra kutu içeceğin diş yüzeyinde su damlaları olduğunu görürsünüz. Sizce bu durumun nedeni nedir?" sorusuna yönelik bulguları aşağıda yer alan tabloda gösterilmektedir.

Tablo 8. Fen bilgisi öğretmen adaylarnın kutunun dış yüzeyinde oluşan su damlalarıın nedenine yönelik bulgular

\begin{tabular}{lll}
\hline Temalar & f & $\%$ \\
\hline Bilimsel olarak kabul edilen cevap & 48 & 70,59 \\
Kavram yanılgısı içeren cevap & 20 & 29,41 \\
Cevap yok & - & - \\
Kavram yanılgııları & & \\
KY-1. Terleme olayı gerçekleşir. & 6 & 30,00 \\
KY-2. Kutu dışndaki buzun erimesi. & 5 & 25,00 \\
KY-3. Buharlaşma gerçekleşir. & 2 & 10,00 \\
KY-4. Kırağılaşma & 2 & 10,00 \\
KY-5. Viskozite & 2 & 10,00 \\
KY-6. Sıvının donarak buz hale geçmesi ile damlalar oluşur. & 2 & 10,00 \\
KY-7. Soğuk olan kutunun dışarıya isı vermesi. & 1 & 5,00 \\
\hline
\end{tabular}

Yukarıda yer alan tabloya göre fen bilgisi öğretmen adaylarının $\% 70,59$ 'u konuya ilişkin bilimsel olarak doğru cevap verirken, \%29,41'i ise kavram yanılgısı içeren cevaplar verdikleri görülmektedir. Öğretmen adaylarının verdikleri cevaplar incelendiğinde en fazla ortaya çıkan kavram yanılgısının "Terleme olayı gerçekleşir (\%30,00)." olduğu belirtilmektedir. Ortaya çıan diğer kavram yanılgılarından bazıları ise yüzde büyüklügüne göre şu şekildedir: "Kutu dışındaki buzun erimesi (\%25,00).", "Buharlaşma gerçekleşir (\%10,00).", "Sivının donarak buz hale geçmesi ile damlalar oluşur (\%10,00).", “Soğuk olan kutunun dışarıya ısı vermesi $(\% 5,00)$." 
Fen bilgisi öğretmen adaylarının maddenin halleri kavram testinde yer alan "Sizce erime, buharlaşma, süblimleşme, donma, yoğunlaşma ve kırağılaşma sırasında maddelerde ne gibi değişimler olur?" sorusuna yönelik bulgular aşağıdaki tabloda gösterilmektedir.

Tablo 9. Fen Bilgisi öğretmen adaylarnın hal değişimi sırasında maddede meydana gelen değişimlere ait bulgular

\begin{tabular}{lll}
\hline Erime -Buharlaşma- Süblimleşme Temaları & F & \% \\
\hline Bilimsel olarak kabul edilen cevap & 16 & 23,52 \\
Kavram yanılgısı içeren cevap & 52 & 76,47 \\
Kavram yanılgıları & & \\
KY-1. Sıcaklık artar. & 18 & 34,62 \\
KY-2. Kütle azalır. & 9 & 17,31 \\
KY-3. Tanecik miktarı azalır. & 8 & 15,38 \\
KY-4. Sıcaklık değişir. & 7 & 13,46 \\
KY-5. Sıcaklık azalır. & 3 & 5,77 \\
KY-6. Kütle değişir. & 2 & 3,85 \\
KY-7. Kütle artar. & 2 & 3,85 \\
KY-8. Tanecik miktarı değişir. & 1 & 1,92 \\
KY-9. Kinetik enerji sabit kalır. & 1 & 1,92 \\
KY-10.Tanecik hareketi sabit olur. & 1 & 1,92 \\
Donma- Yoğunlaşma- Kırağıllaşma Temaları & $\mathbf{F}$ & $\mathbf{\%}$ \\
Bilimsel olarak kabul edilen cevap & 26 & 38,24 \\
Kavram yanılgısı içeren cevap & 53 & 77,94 \\
Cevap yok & 3 & 4,41 \\
Kavram yanılgıları & & \\
KY-1.Sıcaklık azalır. & 18 & 33,96 \\
KY-2.Tanecik miktarı artar. & 9 & 16,98 \\
KY-3.Kütle artar. & 8 & 15,10 \\
KY-4.Sıcaklık değişir. & 7 & 13,95 \\
KY-5.Sıcaklık artar. & 4 & 7,55 \\
KY-6.Kütle azalır. & 3 & 4,92 \\
KY-7.Kütle değişir. & 2 & 3,78 \\
KY-8.Tanecik miktarı değişir. & 1 & 1,88 \\
KY-9.Tanecik hareketi sabit olur. & 1 & 1,88 \\
\hline
\end{tabular}

Yukarıda yer alan tabloda fen bilgisi öğretmen adaylarının erime-buharlaşma-süblimleşme ve donma-yoğunlaşma-kırağılaşma sorularında maddenin 1sı, sıcaklık, kütle, tanecik miktarı ve tanecik hareketinde değişikliklerin meydana gelip gelmeyeceğine dair cevapları yer almaktadır. Erime-buharlaşma-süblimleşme teması incelendiğinde fen bilgisi öğretmen adaylarının $\% 23,52$ 'sinin bilimsel olarak doğru, \%76,47'sinin ise kavram yanılgısı içeren cevaplar verdikleri görülmektedir. Ortaya çıkan kavram yanılgıları incelendiğinde en fazla "sıcaklık artar (\%34,62)." şeklinde kavram yanılgısı olduğu 
belirlenmiştir. Konuya ilişkin diğer bazı kavram yanılgıları ise yüzde büyüklüklerine göre sırasıyla şu şekildedir: "Kütle azalır (\%17,31).", "Tanecik miktarı azalı (\%15,38).", "Sicaklik değişir (\%13,46).", "Sicaklı azalır (\%5,77).", "Tanecik hareketi sabit olur (\%1,92)." Donma-yoğunlaşma-kırağılaşmaya dair temalar incelendiğinde, fen bilgisi öğretmen adaylarının \%77,94'ünün kavram yanılgısına sahip oldukları görülmektedir. Yukarıda yer alan tablo incelendiğinde konuya ilişkin en fazla ortaya çıan kavram yanılgısının "Sıcaklık azalır (\%33,96)." olduğu görülmektedir.

Fen bilgisi öğretmen adaylarının maddenin halleri kavram testinde yer alan "Maddenin düzensiz halden düzenli hale geçtiği durumlara örnekler veriniz. Isı ve sıcaklıkla bu olayların bir ilişkisi var mıdır?" sorusuna yönelik bulguları aşağıda yer alan tabloda ifade edilmektedir. Maddenin düzensiz halden düzenli hale geçişine yönelik sahip oldukları kavram yanılgıları yer almaktadır.

Tablo10. Fen bilgisi öğretmen adaylarmın maddenin düzensiz halden dïzenli hale geçişine yönelik bulgularn

\begin{tabular}{lll}
\hline Temalar & f & \% \\
\hline Bilimsel olarak kabul edilen cevap & 45 & 66,18 \\
Kavram yanılgısı içeren cevap & 15 & 22,06 \\
Cevap yok & 8 & 11,76 \\
Kavram yanılgıları & & \\
KY-1. Sıcaklık azalır. & 4 & 26,65 \\
KY-2. Madde ısı ve sıcaklık alarak düzenli hale geçer. & 3 & 20,00 \\
KY-3. Gaz madde ısı alarak sıvıya dönüşür. & 2 & 13,33 \\
KY-4. Isı ve sıcaklık değişimi olur. & 1 & 6,67 \\
KY-5. Madde ısı vererek donar ve sıcaklık değişir. & 1 & 6,67 \\
KY-6. Madde sıcaklık alarak düzenli hale geçer. & 1 & 6,67 \\
KY-7. Madde ısı alır ve sıcaklığı artar. & 1 & 6,67 \\
KY-8. Katı maddenin ısı alarak sıvı hale geçmesi. & 1 & 6,67 \\
KY-9. Tereyağın ısı alarak sıvılaşması. & 1 & 6,67 \\
\hline
\end{tabular}

Yukarıda yer alan tabloya göre fen bilgisi öğretmen adaylarının \%66,18'i maddenin düzensiz halden düzenli hale geçişinde ve bu durumun 1sı-sıcaklıkla ilgisini doğru örneklerle açıklamışlardır. Öğretmen adaylarının \%22,06's ise kavram yanılgısı içeren cevaplar verirken, \%11,76'sının, konuya dair herhangi bir açıklama yapmadığı görülmektedir. Elde edilen cevaplarda, en fazla ortaya çıkan kavram yanılgısı "Sıcaklık azalır $(\% 26,65)$." şeklindedir. Konuya ilişkin diğer kavram yanılgılarından bazıları ise yüzde büyüklügüne göre şu şekildedir: "Madde ısı ve sıcaklık alarak düzenli hale geçer (\%20,00).", 
"Gaz madde isı alarak sivıya dönüşür (\%13,33).", "Isı ve sıcaklık değişimi olur (\%6,67).", "Madde ısı vererek donar ve sıcaklık değişir (\%6,67).", "Madde sıcaklık alarak düzenli hale geçer $(\% 6,67)$. ., "Madde ısı alı ve sıcaklı̆̆ artar $(\% 6,67)$."

\section{Tartışma ve Sonuç}

Isı ve sıcaklık, içinde soyut bilgiyi barındırması ve kavram yanılgılarına sürekli olarak rastlanmasından dolayı, anlaşılması zor bir konu olarak nitelendirilmektedir (Şenocak, Diber, Sözbilir, Taşkesenligil, 2003). Alan yazında öğrencilerin $15 ı$ kavramına ilişkin kavram yanılgılarına sahip olduklarını gösteren birçok çalışmaya rastlanmıştır (Bar ve Travis, 1991; Carlton, 2000; Gürses, Doğar, Yalçın ve Canpolat, 2002; Jones, Carter ve Rua, 2000). Fen bilgisi öğretmen adaylarının isı kavramına ilişkin en fazla ortaya çıkan kavram yanılgısının "enerji dönüşümü" olduğu görülmektedir. Bununla birlikte fen bilgisi öğretmen adaylarında "fiziksel enerji", "enerji alışverişi”, "enerji farkı", "çevreye yayılan enerij", ve "aktarılan enerji" ve "iç enerji" şeklinde daha çok enerjiye yönelik kavram yanılgısı olduğu belirlenmiştir. Bu durum öğrencilerin $1 s ı$ kavramını enerji kavramı ile birlikte düşünmesinden kaynaklanmış olabilir. Bireyler küçük yaştan itibaren "1sı enerjisi" kavramını çevrelerinde duymakta ve görsel olarak da birçok yerde görmektedirler. Fen derslerinde ise enerjinin hiçbir zaman yoktan var ya da vardan yok olamayacağı bilgisini öğrenmektedirler. Öğretmen adaylarının ısıyı tanımlarken enerji dönüşümü ifadesini kullanmaları, 1sının bir enerji çeşidi olması ve enerjinin yok edilemediği bilgisini düşünmelerinden kaynaklanabilir. Ayrıca alanyazın tarandığında 1sı kavramına ilişkin "1sı maddenin ortalama kinetik enerjisidir" şeklinde kavram yanılgılarının olduğu da görülmektedir (Aydoğan Güneş ve Gülçiçek, 2003; Aytekin, 2010; Bayram, 2010; Aydın, 2007). Benzer şekilde de Uzoğlu ve Gürbüz (2013) öğretmen adaylarında ısının bir iç enerji olduğuna dair kavram yanılgısına sahip olduğunu belirtmiştir. Ayrıca Akgül (2010) çalışmasında, fen bilgisi öğretmen adaylarının ısının potansiyel enerji olduğuna yönelik kavram yanılgılarının olduğunu belirtmiştir. Elde edilen sonuçların alan yazın ile örtüştüğü ifade edilebilir. Alan-yazın tarandığında, öğrencilerin sıcaklık kavramına yönelik kavram yanılgılarının bulunduğuna ilişkin, farklı çalışmaların yer aldığı görülmektedir (Başer ve Çataloğlu, 2005; Kırıkkaya ve Güllü, 2008; Jara-Guerro, 1993; Lewis ve Linn, 1994). Sıcaklık kavra- 
mının tanımlarına bakıldığında fen bilgisi öğretmen adaylarında, en fazla ortaya çıkan kavram yanılgısının "enerji" olduğu görülmektedir. Bu kavram yanılgısının ortaya çıkma nedeni ısı ve sıcaklık kavramlarının öğrenciler tarafından ayırt edilememesi olabilir. Akgül (2010) çalışmasında, fen bilgisi öğretmen adaylarında sıcaklığın bir enerji olduğuna dair kavram yanılgıları olduğunu ifade etmiştir. Fen bilgisi öğretmen adaylarında sıcaklık kavramına ilişkin ortaya çıkan diğer bazı kavramları "alınan verilen enerji", "kinetik enerji durumu", "toplam kinetik enerji” şeklindedir. Ayrıca Uzoğlu ve Gürbüz (2013) çalışmasında öğretmen adaylarında, "sıcaklık bir maddenin aldığı ya da verdiği enerjidir.", "sicaklık maddenin sahip olduğu enerjidir", "sıcaklık bir maddenin aldığı veya verdiği enerjidir" şeklinde kavram yanılgılarının olduğunu belirtmiştir. Çalışmadan elde edilen sonuçlar, alan-yazın ile örtüşmektedir.

Maddenin halleri konusu ısı ve sıcaklıkla doğrudan ilişkili bir konu olmasından dolayı maddenin hallerine ilişkin de öğrencilerde kavram yanılgılarının olduğu tespit edilmiştir. Erime-buharlaşma-süblimleşme-donma-yoğunlaşma-kırağılaşma sırasında maddenin 1sı, sıcaklık, kütle, tanecik miktarı ve tanecik hareketinde ne gibi değişikliklerin meydana geleceğine dair fen bilgisi öğretmen adaylarının kavram yanılgısına sahip oldukları tespit edilmiştir. Fen bilgisi öğretmen adaylarında erime-buharlaşma-süblimleşme kavramlarına ilişkin en fazla orta çıan kavram yanılgısının "sıcaklık artar" olduğu sonucuna ulaşılmıştır. Diğer kavram yanılgılarının ise kütle azalır, kütle artar, sıcaklık değişir, sıcaklık azalır olduğu belirlenmiştir. Donma-yoğunlaşma-kırağılaşma sırasında ne gibi değişikliklerin meydana geleceğine dair en fazla ortaya çıkan kavram yanılgısı "sıcaklık azalır" şeklindedir. Ortaya çıkan diğer kavram yanılgıları ise tanecik miktarı artar, tanecik hareket sabit olur, kütle artar, sıcaklık değişir, kütle değişir, kütle azalır olarak belirlenmiştir. Görüldüğü üzere öğretmen adaylarının hal değişimi sırasında maddeye verilen ve maddeden alınan ısıya yönelik açıklamalarda bulunmadıkları görülmektedir. Bazı öğretmen adaylarının ısı tanımlamalarına bakıldığında, enerji dönüşümü, enerji alışverişi ifadelerini kullandıkları sonucuna ulaşılmıştır. Mevcut soruda $1 s ı$ kavramına değinmeme nedeni 1sıyı enerji dönüşümü ve alışverişi olarak algılamalarından dolayı, hal değişimi sırasında enerjinin sabit kalacağını düşünmeleri olabilir. Öğretmen adayları erime-buharlaşma-süblimleşme sırasında sıcaklığın artacağını, donma-yoğunlaşmakırağılaşma sırasında ise sıcaklığın azalacağını düşünmektedirler. Bu durum 
öğretmen adaylarının hal değişimi ve sıcaklık arasında doğru bağlantıyı kuramadıklarını göstermektedir. Öğretmen adayları erime sırasında katı haldeki bir maddenin sıvı hale geçmesinin ortam sıcaklığının artmasıyla mümkün olacağını düşündükleri için sıcaklık artar kavram yanılgısına sahip olmuş olabilirler. Bununla birlikte donma, yoğunlaşma ve kırağılaşma olaylarının erime, buharlaşma ve süblimleşmenin tersi olacağını düşünerek, erimede sıcaklık artışı meydana geliyor ise, donmada bunun tam tersi olacağ için sıcaklık azalır şeklinde bir düşünce yapısı oluşturmuş olabilirler. Bu durum öğretmen adaylarının 1sı-sıcaklık ve hal değişimi arasında doğru bağlantıları kuramadıklarını ve hal değişimi sırasında sıcaklığın değişmeyeceğine dair bilgilerinde eksiklerin olduğunu göstermektedir. Alan yazında da bu sonuçları destekler nitelikte çalışmalar yer almaktadır (Demirci ve Sarıkaya, 2004; Gönen ve Akgün, 2005; Aytekin, 2010; Bayram, 2010). Ayrıca öğretmen adaylarının hal değişimi sırasında maddenin tanecik miktarı ve hareketi ile ilgili yanlış kavramaları olduğu belirlenmiştir. Alanyazında bu sonuçla örtüşen çalışmalar yer almaktadır (Osborne ve Cosgrove, 1983; Türkoğuz ve Yankayış, 2015; Stavy, 1990). Alan yazın incelendiğinde, hal değişiminin madde miktarına bağlı olduğuna ilişkin kavram yanılgılarının yer aldığı çalışmalar da görülmektedir (Akgül, 2010; Bayram, 2010; Griffiths ve Preston, 1992; Keser, 2007; Karakuyu, Uzunkavak, Tortop, Bezir ve Özek, 2006; Othman, vd., 2007). Ayrıca Özmen ve Kenan (2007) çalışmasında, öğrencilerin ısı değişimi sonucunda, maddenin tanecik miktarının değiştiğini düşündüklerini ifade etmişlerdir. Alan yazın incelendiğinde, 1sı farkından dolayı meydana gelen hal değişimlerinde, bireylerde kütlenin azalacağına ilişkin kavram yanılgıları olduğu belirlenmiştir (Erkaçan, Moğol, Ünsal, 2012; Kırıkkaya ve Güllü, 2008). Bu durumun ortaya çıkma nedeni öğretmen adaylarının buharlaşma anında, sıvı haldeki bir maddenin gaz hale geçmesi sonucunda sıvı da oluşan azalmayı düşünmeleri olabilir. Ayrıca öğretmen adaylarının tanecikleri mikroskobik boyutta düşünememeleri, maddenin tanecikli yapısına ilişkin eksik bilgileri olması ve kütlenin korunumunu kavrayamamaları da bu kavram yanılgılarının ortaya çıkmasına neden olmuş olabilir. Ayrıca bazı öğretmen adayları hal değişimi sırasında tanecik hareketinin sabit olacağını düşünürken, bazı öğretmen adayları ise ısının tanecik hareketi olduğunu düşünmektedir. Bu durum öğretmen adaylarının ısı ve maddenin tanecik hareketi arasında yanlış bir bağlantı kurulduğunu göstermektedir. 
"Okuldaki koridorlar su ile yıkandıktan ya da paspasla silindikten sonra serinleme hissedilir. Bu serinleme hissi neden kaynaklanmaktadır?" sorusuna yönelik elde edilen cevaplar incelendiğinde, fen bilgisi öğretmen adaylarının "sudan koridora soğukluk geçer", "sıcaklık suya geçer", "sıcaklık alışverişi olur" şeklinde kavram yanılgılarına sahip oldukları görülmüştür. Elde edilen bu sonuçlar, Şendur, Toprak ve Pekmez (2008) çalışmasında "Koridorlar su ile yıkandığında ya da paspaslandığında, su yerden daha soğuk olduğu için, kısa bir süreliğine yerden 1sı ve sıcaklığı alır ve ortam serinler" şeklinde belirledikleri kavram yanılgısıyla örtüşmektedir. Öğretmen adaylarının buharlaşma olayını günlük yaşam örneklerinde açıklayamadıkları belirlenmiştir. Öğretmen adaylarının buharlaşma olayını ısı kavramıyla ilişkilendiremedikleri, bu durumu genel olarak sıcaklığa bağladıkları görülmektedir. Öğretmen adaylarının sıcaklık alışverişi ile serinleme hissinin gerçekleştiğini düşünmelerinin nedeni, serinleme hissinin sıcaklık azalması sonucunda ortaya çıktığını düşünmelerinden ve bu nedenle sıcaklık alışverişinin olduğunu düşünmelerinden kaynaklanmış olabilir. "Sıcak bir havada serinlemek için kutu içecek aldığınızı düşünün. Eve geldiğinizde içeceğin soğuması için kısa bir süre buzluğa içeceği koydunuz. Buzluktan alıp içmeye başladınız. Bir süre sonra kutu içeceğin dış yüzeyinde su damlaları olduğunu görürsünüz. Sizce bu durumun nedeni nedir?" sorusuna ilişkin fen bilgisi öğretmen adaylarının "terleme olayı gerçekleşir", "kutu dışındaki buzun erimesi", "buharlaşma gerçekleşir", "kırağılaşma", "Viskozite", "sıvının donarak buz hale geçmesi ile damlalar oluşur", "soğuk olan kutunun dışarıya ısı vermesi" şeklinde bazı kavram yanılgılarına sahip oldukları tespit edilmiştir. Görüldügü üzere öğretmen adaylarının yoğuşma kavramını günlük yaşam örneğinde açıklayamadıkları ortaya çıkmıştır. Kutu dışındaki buzun erimesi şeklinde ortaya ç1kan kavram yanılgısının nedeni, öğretmen adaylarının buzluktaki kutu içeceğin dış yüzeyinin bir süre sonra buz tutacağı ve bu kutu içecek buzluktan çıkarıldığında, yüzeyde bulunan buzların eriyeceğini düşünmelerinden kaynaklanmış olabilir. Ayrıca kutu içeceğin dışında oluşan farklılıktan yola çıkarak, yüzeydeki buzun buharlaşarak tekrar yüzeye tutunması olarak düşünülmesinden dolayı, buharlaşma gerçekleşir kavram yanılgısının ortaya çıktı̆ 1 da söylenebilir. Bu soruya benzer olarak Osborne ve Cosgrove (1983) gerçekleştirdikleri çalışmada, içinde buz olan ve ağzı kapalı olan bir cam kavanozun dış yüzeyinde biriken suyun kaynağının ne olduğuna dair soruyu öğrenci- 
lere sormuşlardır. Öğrencilerin ise soruya ilişkin camın soğukluk oluşturduğundan dolayı ve havadaki suyun cama yapışmasından kaynaklı, kavanozun dışında suyun biriktiği şeklinde kavram yanılgılarının olduğunu belirlemişlerdir. Bununla birlikte Demircioğlu (2003) sınıf öğretmeni adaylarına, araştırma sorusuna benzer bir soru sormuş ve öğretmen adaylarında, soğukluğun bardağın içerisinden gelmesinden ve suya dönüşmesinden kaynaklı olarak bardağın dış yüzeyinde su birikimi olduğuna dair kavram yanılgılarının bulunduğunu ifade etmiştir. Ayrıca aynı cins maddeler arasındaki çekim kuvveti olan kohezyon kavramı, fen bilgisi öğretmen adaylarında ortaya ç1kan diğer bir kavram yanılgısıdır. Öğrencilerin bu kavramı kullanmasının nedeni, su damlalarının bir arada kutu içeceğin yüzeyine yapıştığını düşünmesinden kaynaklanmış olabilir.

"Avucumuza bir parça buz alıp beklediğimizde bir süre sonra buz parçasının eriyerek suya dönüştüğünü görürüz. Bunun nedeni sizce ne olabilir?” sorusuna yönelik elde edilen bulgular incelendiğinde fen bilgisi öğretmen adaylarının kavram yanılgısı içeren cevaplar verdikleri görülmektedir. Fen bilgisi öğretmen adaylarında ortaya çıkan kavram yanılgılarının "ısının iletim yoluyla yayılmasından dolayı buz erir", "buz sıcaklık kaybeder", "buzdaki ısı elimize geçer" ve "elimizin sıcaklığı buza geçer." olduğu sonucuna ulaşılmıştır. Elde edilen bu sonuç Kesidou ve Duit (1993) çalışmasında öğrencilerin "sıcaklık bir maddeden diğerine geçer" şeklindeki kavram yanılgısı ile örtüşmektedir. Öğretmen adaylarının erime konusuna ilişkin günlük yaşam örneğini doğru ve bilimsel bir şekilde açıklayamadıkları görülmektedir. Ele alınan buzun bir süre sonra suya dönüşme nedeni, buzun elimizden 1sı alması ve bunun sonucunda erime olayının gerçekleşmesidir. Fakat öğretmen adayları buzdaki ısının elimize geçmesinden dolayı erime olayının gerçekleştiğini düşünmektedir. Ayrıca bazı öğretmen adayları ise elimizin sıcaklığından kaynaklı olarak buzun eridiğini ifade etmektedir. Bu durum öğretmen adaylarının ısı transferi, ısının akış yönü ve ısı ve sıcaklığın erime olayındaki rolüne yönelik bilgilerinde bilimsel olarak yanlışlıklar olduğunu göstermektedir. Ayrıca ortaya çıkan başka bir kavram yanılgısı ise "buz hava ile temas ettiği için erir." şeklindedir. Yıldırım ve Konur (2014) gerçekleştirdiği çalışmada, öğrencilerin kolonya dökülen elin serinlemesini, kolonyanın hava ile reaksiyona girmesinden kaynaklandığını düşündüklerini tespit etmişlerdir. Elde edilen bu sonuçlar birbiriyle örtüşmektedir. Öğretmen adayları buz ve havanın reaksiyonu sonucunda erimeye neden olduğunu düşünmelerinden 
dolayı bu sonuç ortaya çıkmış olabilir. Ortaya çıkan başka bir kavram yanılgısı ise sıcaklık alışverişinden dolayı buzun eridiği ifadesidir. Bazı öğretmen adaylarının 1sı tanımlamaları incelendiğinde, 1sıyı sıcaklık dengelenmesi olarak açıkladıkları görülmektedir. Öğretmen adaylarının ısıyı sıcaklık dengelemesi olarak gördükleri ve buzun erimesini de sıcaklık alışverişine bağladıkları görülmektedir. Dolayısıyla ısı kavramını sıcaklık alışverişi olarak zihnine yerleştiren öğretmen adayları, kavram yanılgısına sahip olmalarından dolayı buzun erimesini de sıcaklık alışverişine bağladıkları söylenebilir. Ayrıca öğretmen adaylarının özellikle hal değişimi sırasında ısı kavramından daha çok sıcaklık kavramını ön planda tutmaları günlük yaşamda kullanılan dile bağlı olarak edinilen kavram yanılgılarından kaynaklanmış olabilir.

“Grafikte naftalin, kükürt, bakır ve kurşunun erime sıcaklıkları verilmiştir. Hangi maddenin donma sıcaklığı en yüksektir ve hangi maddeyi eritmek daha zordur?" şeklinde öğrencilere soru sorulmuştur. Fen bilgisi öğretmen adaylarının maddelerin donma sıcaklığına dair kavram yanılgılarına sahip oldukları belirlenmiş ve en fazla "naftalinin erime noktası düşük olduğu için, donma sıcaklığı en yüksektir" şeklinde kavram yanılgısının olduğu sonucuna ulaşılmıştır. Bu kavram yanılgısının ortaya çıkma nedeni, katı bir maddenin eridiği sıcaklıkta, bahsi geçen maddenin sıvı halinin de aynı sıcaklıkta donduğuna dair eksik bilgilerinin bulunmasından kaynaklanmış olabilir. Alan yazında maddelerin erime ve donma sıcaklığı arasında yanlış ilişkilerin kurulduğunu ve bu doğrultuda öğrencilerde kavram yanılgılarının oluştuğunu belirten çalışmalar yer almaktadır (Demircioğlu, Vural ve Demircioğlu, 2014; Kırıkkaya ve Güllü, 2008). Bayrakçı da (2007) gerçekleştirdiği çalışmada buna benzer olarak, öğrencilerde donma sıcaklığına dair "erime sıcaklığı yüksek olanını donma sıcaklığı düşük olduğundan, naftalinin donma noktası en yüksektir", "grafiğe göre, naftalin daha düşük sıcaklıkta eridiği için diğerlerine göre daha çabuk donar ve donma sıcaklığı en yüksek naftalin olur" şeklinde kavram yanılgıları olduğunu ifade etmiştir. Eritilmesi zor olan madde ile ilgili bulgular incelendiğinde ise fen bilgisi öğretmen adaylarının kavram yanılgısına sahip olduğu tespit edilmiştir. Öğretmen adaylarında konuya ilişkin "naftalinin erime sıcaklığı düşük olduğu için, eritilmesi daha zordur." ve "naftalin en soğuk madde olduğu için eritilmesi daha zordur." şeklinde kavram yanılgılarının da olduğu görülmektedir. Ayrıca Bayrakçı (2007) çalışmasında söz konusu maddelerinin hangisinin daha zor eriyeceğine dair "naftalini eritmek en zordur. Çünkü en geç naftalin donar" şeklinde kavram 
yanılgısı olduğunu belirlemiştir. Belirlenen bu ifadeler ile çalışmadan elde edilen sonuçlar birbiri ile örtüşmektedir. Ayrıca yukarıda bahsi geçen kavram yanılgılarının oluşumu, ögrencilerin grafik okumada yetersiz olmalarından kaynaklanmış olabilir. Öğretmen adaylarına “Maddenin düzensiz halden düzenli hale geçtiği durumlara örnekler veriniz. Isı ve sıcaklıkla bu olayların bir ilişkisi var mıdır?" şeklinde başka bir soru sorulmuş ve fen bilgisi öğretmen adaylarının kavram yanılgısına sahip oldukları belirlenmiştir. Bu yanılgılar dikkate alındığında en fazla ortaya çıkan kavram yanılgısının "s1caklık azalır" olduğu tespit edilmiştir. Bu durum öğretmen adaylarında, hal değişimi sırasında sıcaklığın değişmeyeceğine dair bilgilerinde eksiklerin olduğunu göstermektedir. Alanyazında da bu sonuçları destekler nitelikte çalışmalar yer almaktadır (Kocakülah ve Kocakülah, 2002; Demirci ve Sarıkaya, 2004; Gönen ve Akgün, 2005; Aytekin, 2010; Bayram, 2010).

"Su $0{ }^{\circ} \mathrm{C}$ de donarak buz haline geçer. Su donarken enerjisinin tamamını verdiğinden, $0{ }^{\circ} \mathrm{C}$ deki buzun $1 s ı s ı$ yoktur." ifadesinin doğruluğu ya da yanlışlığına dair öğretmen adaylarının kavram yanılgıları olduğu tespit edilmiştir. Öğretmen adaylarında "su donarken ısısının tamamını verir", "1sısının tamamını hal değişiminde kullandığı için 1sısı yoktur", "sıfır başlangıç (nötr sıcaklık) olduğu için ısısı yoktur" şeklinde bazı kavram yanılgılarının olduğu belirlenmiştir. Hal değişiminde 1 sı alıverişi olmaktadır ve sıcaklık değerinin sıfır olması ısının olmadığı anlamına gelmemektedir. Fakat bazı öğretmen adayları sıcaklık değerinin sıfır olmasını ısı ile doğrudan ilişkilendirmişlerdir. $\mathrm{Bu}$ ifadeler öğretmen adaylarının matematiksel olarak sıfırı $\left(0^{\circ} \mathrm{C}\right)$ yokluk bildiren sayı olarak düşünmelerinden kaynaklanmış olabilir. Gürdal Kazanc1oğlu (2008) öğrencilerin sıcaklık değerinin sıfır olmasını ısının olmadığı şeklinde düşündüklerini ifade etmiştir. Elde edilen sonuçlar ile Gürdal Kazanc1oğlu'nun (2008) yaptığı çalışma sonuçları örtüşmektedir. Öğretmen adaylarına hal değişim grafiği verilerek, bu grafiğin ne olarak adlandırıldığı ve grafiğin bölgelerinde ne gibi değişikliklerin olduğu sorulmuştur. Öğretmen adaylarından bazıları bu grafiği "erime grafiği" ve "1sı zaman" grafiği olarak adlandırmıştır. Bu durum bazı öğrencilerin grafik anlama becerisinin yeterli düzeyde olmamasından kaynaklanmış olabilir. Grafiğin I. ve III. bölgelerde meydana gelen değişikliklerin aynı olması beklenmektedir. Grafiğin I. ve III. bölgesinde sıcaklığın artması, düzensizliğin artması, tanecikler arası çekim kuvvetinin azalması gibi durumların olması beklenmektedir. II. Bölgede ise 
sıcaklığın sabit kalması, tanecikler arası çekim kuvvetinin azalması ve düzensizliğin artması gibi durumlar ortaya çımaktadır. Fakat öğretmen adaylarının düşünceleri incelendiğinde, grafiğin I. bölgesine ilişkin kavram yanılgisı bulunmazken, III. bölgesine ilişkin bu bölgede yoğuşma olduğuna ilişkin kavram yanılgısı yer almaktadır. Grafiğin II. bölgesine ilişkin ise öğretmen adaylarında kaynama olayının meydana geldiğine ilişkin kavram yanılgısı olduğu belirlenmiştir. Fakat II. bölgede erime olayı gerçekleşmektedir. Bu durum öğretmen adayının erime ve kaynama olaylarını karıştırdıklarını göstermektedir. Alan yazında erime, kaynama gibi hal değişim olaylarının birbiri ile karıştırıldığı ifade eden çalışmalar yer almaktadır (Paik, Kim, Cho, Park, 2004). Öğretmen adaylarının bazılarının grafik okumada eksikliklerinden dolayı, bu kavram yanılgılarının ortaya çıktığı ifade edilebilir. Görüldüğü üzere öğretmen adaylarının hal değişimi ve isı-sıcaklık arasında bilimsel olarak doğru bağlantılar kuramadıkları söylenebilir.

\section{Öneriler}

\section{Uygulamaya yönelik öneriler}

- Öğretim üyeleri ders öncesinde öğretmen adaylarında var olan kavram yanılgılarını belirleyip, ders akışını bu yanılgıları göz önüne alarak düzenleyebilir.

- Fen bilgisi öğretmen adaylarının 1si-sıcaklık ve maddenin halleri konularına ilişkin kavram yanılgılarının giderilmesi için TGA (tahmin et-gözle-açıkla) yöntemi kullanılabilir.

- Maddenin halleri ve isı-sıcaklık konularının öğretmen adaylarının zihinlerinde daha iyi somutlaştırılması için, derslerde simülasyon ve animasyonlar kullanılabilir.

- Isı-sıcaklık ve maddenin halleri konularına ilişkin öğretmen adaylarının kendi argümanlarını oluşturması sağlanarak, kavram yanılgıların fark edecekleri etkinlikler argümantasyon yöntemi içerisinde kullanılabilir.

- Isı-sıcaklık ve maddenin halleri konularına dair deney düzenekleri tasarlanarak, bilgilerin somutlaştırılması sağlanabilir. 
- Konuya ilişkin olarak laboratuvar derslerinde gerçekleştirilen kapalı uçlu deneyler yerine, öğretmen adaylarının aktif olduğu deney türleri kullanılabilir.

\section{Araştırmacılara yönelik öneriler}

- İlkokul, ortaokul ve lise kademelerinin tümünü kapsayacak şekilde bir araştırma yapılabilir.

- Ülke çapında, farklı bölgelerde yer alan eğitim fakültelerini kapsayacak şekilde bir araştırma yapılabilir.

- Sınıf düzeyi değişkeninin de kullanılacağı daha geniş bir araştırma yapilabilir.

- Vakıf ve devlet üniversitelerinde öğrenim gören öğretmen adaylar1nın kavram yanılgılarının karşılaştırılmasına yönelik farklı çalışmalar tasarlanabilir. 


\title{
EXTENDED ABSTRACT
}

\section{An Analysis of the Relationship between Pre-service ScienceTeachers' Misconceptions Regarding Heat-Temperatureand Stateof Matter}

\author{
Evrim Ural - Ayşe Rabia Başaran Uğur \\ Sütçü Imam University- Erciyes University
}

\begin{abstract}
"States of Matter" and "Heat-Temperature" topics include concepts such as solid, liquid, gas, melting, freezing, evaporation, condensation, sublimation, frosting, which are at the basis of science. Understanding the mentioned concepts will provide the background for understanding the structure of matter and understanding the topics such as atom and thermodynamics in the future. These concepts are intertwined with many events that individuals experience in daily life from an early age. This situation shows that the subjects of heat-temperature and states of matter are inseparable. It shows that a student who does not understand the fundamental reason underlying the melting process of solid is related to heat and temperature concepts cannot establish a connection between heat-temperature and states of matter. Also, s/he and cannot learn these concepts in a meaningful way. Studies conducted in physics, chemistry, and biology education reveal that despite the instruction given, misconceptions related to these concepts occur at all education levels (Alwan, 2011; Caleon and Subramaniam, 2010).
\end{abstract}

Pre-service science teachers' misconceptions about these concepts should be investigated, and they need to understand that these concepts are interrelated before they graduate. In the literature, there are many studies on the misconceptions in "Matter, the States of Matter" subject (Abraham, Williamson and Westbrook, 1994; Griffths and Preston, 1992), "Heat and Temperature" (Alwan, 2011; De Berg, 2008) subject. However, no studies examine the relationship between pre-service teachers' misconceptions about "The States of Matter" and "Heat-temperature." Therefore, this study is essential since it determines the relationship between preservice science teachers' misconceptions about the states of matter, heat, 
and temperature and will contribute to the literature. This study investigates the relationship between pre-service science teachers' misconceptions regarding heat-temperature and states of matter. For this purpose, the study seeks the answer to the following question: "What is the relationship between pre-service science teachers' misconceptions about heattemperature and the states of matter?"

In this study, phenomenology design, which is one of the qualitative research designs, was used. This design was preferred because it aimed to examine the relationship between pre-service science teachers 'misconceptions regarding heat-temperature and states of matter. The pre-service teachers' past experiences related to the subject were in question. On the other hand, criterion sampling included in purposive sampling was preferred. The study group of the study consists of 68 pre-service science teachers studying in the third grade of the science teaching program at a state university's education faculty in the spring semester of the 2017-2018 academic year. In this study, the "Heat-Temperature Concept Test" and "States of Matter Concept Test," which researchers prepared by taking expert views and consisted of open-ended questions, are used as data collection tools. The questions in the "Heat-Temperature Concept Test" ask for the definitions of heat and temperature concepts scientifically. They ask to explain how the change of state occurs due to heat exchange and what kind of changes will appear due to this change. They also ask the participants to guess the materials' freezing temperatures by given melting temperatures and the melting state of the materials. The questions in the "States of Matter Concept Test" aim to interpret the state change graph, reveal the properties of the change of matter process. They also ask to associate the state change with some situations we encounter daily and show how the state changes with heat and temperature. The data is collected in the spring semester of the 2017-2018 academic year. Descriptive, content, and numerical analysis are used in the analysis of the data. Content analysis is preferred due to the aim of analyzing the relationships between the concepts in depth. Numerical analysis is carried out to make comparisons with percentage values easily. It is seen that the most common misconception of pre-service science teachers about the concept of heat is "energy conversion." However, some misconceptions about energy such as "physical energy," "energy exchange," "energy difference," "energy 
spread to the environment," "transferred energy," and "internal energy" are determined too. This finding may be due to the participants' thinking of the concepts of heat and energy together. Also, when the literature displays that there are misconceptions about the concept of heat, such as "heat is the average kinetic energy of matter" (Aytekin, 2010; Bayram, 2010; Aydın, 2007). The most common misconception among the participants is "energy" related to the temperature concept. This misconception displays that the participants cannot distinguish the concepts of heat and temperature. Uzoğlu and Gürbüz (2013), in their study, reveal some misconceptions such as, "temperature is the energy that a substance takes or gives away," "temperature is the energy of a substance."

It is concluded that the most common misconception among the participants about the concepts of melting-evaporation-sublimation is the "temperature increases" misconception. The other misconceptions are that "the mass decreases," "the mass increases," "the temperature changes," "the temperature decreases." The most common misconception about the changes that occur during freezing-condensation-frosting is "the temperature decreases." Other misconceptions areas "the amount of particle increases", "particle motion becomes constant", "mass increases", "temperature changes", "mass changes", "mass decreases". As can be seen, the participaaants don't explain the heat given to and taken from the substance during a state change. This finding shows that the participants can not establish the correct connections between heat-temperature and state change process. They have insufficient knowledge that the temperature would not change during the state change process. There are also studies in the literature that support these findings (Demirci ve Sarıkaya, 2004; Aytekin, 2010; Bayram, 2010). Besides, the participants have misconceptions about the number of particles and their movement during the state change. Some studies have similar findings (Osborne and Cosgrove, 1983; Stavy, 1990). The studies in the literature display a widespread misconception as "the state change process depends on the amount of matter" (Griffiths and Preston, 1992; Othman, et al., 2007). Also, while some of the participants think that the particle motion will be constant during the process, some think that heat is particle motion. This finding shows a misconnection between the particle motion and heat transfer in the participants' mental structures. The findings related to the melting of the ice reveal that the participants 
have misconceptions such as "ice melts due to the spread of heat through conduction," "ice loses temperature", "the heat in the ice passes into our hands," and "the temperature of our hands passes to ice". This finding coincides with the misconception displayed in Kesidou and Duit (1993) study that "temperature passes from one item to another." The participants think that melting occurs since the heat in the ice transfer to our hands. Besides, some of the participants state that the ice melts due to the temperature of our hands. This statement shows scientific inaccuracies in the pre-service teachers' knowledge about heat transfer, the flow direction of heat, and the role of heat and temperature in melting.

\section{Kaynakça / References}

Abraham, M. R., Williamson, V. M. and Westbrook, S. L. (1994). A cross-agestudy of the understanding of five chemistry concepts. Journal of Research in Science Teaching, 31(2), 147-165.

Akgül, P. (2010). Üst kauramsal faaliyetlerle zenginleştirilmiş kauramsal değişim metinlerinin fen bilgisi ögretmen adaylarmm "ısı ve sicaklk" konusundaki kavramsal anlamalarnna etkisi. Yüksek lisans tezi. Gazi Üniversitesi Eğitim Bilimleri Enstitüsü, Ankara.

Alwan, A. A. (2011). Misconception of heat and temperature among physics students. Procedia Social and Behavioral Sciences, 12, 600-614.

Arastman, G., Öztürk Fidan, İ. ve Fidan, T. (2018). Nitel araştırmada geçerlik ve güvenirlik: kuramsal bir inceleme. YYÜ Eğitim Fakültesi Dergisi, 15(1), 37-75.

Aş̧̧, Z., Özkan, Ş. ve Tekkaya, C. (2001). Student's misconceptions about respiration, Eğitim ve Bilim, 26(120), 29-36.

Ayas, A., Coştu, B. ve Karamustafaoğlu, S. (2002). Simfföğretmeni adaylarnnn çözeltiler konusundaki kavram yanlgilan ve bu yanllglarm kavram haritası tekniğgi ile giderilmesi. V.Ulusal Fen Bilimleri ve Matematik Eğitimi Kongresinde sunulmuş bildiri, 16-18 Eylül 2002, Ankara.

Aydın, Z. (2007). Isi ve sicaklik konusunda rastlanan kavram yanilgilar ve bu kavram yanllgilarmm giderilmesinde kavram haritalarnnin kullanılması. Yüksek lisans tezi, Yüzüncü Yll Üniversitesi Fen Bilimleri Enstitüsü, Van.

Aydoğan, S., Güneş, B. ve Gülçiçek, Ç. (2003). Isı ve sıcaklık konusunda kavram yanılgıları. Gazi Eğitim Fakültesi Dergisi, 23(2), 111-124. 
Aytekin, Ü. (2010). Ortaöğretim öğrencilerin ısı-sıcaklık konusundaki bilgilerin belirlenmesi ve bu bilgilerin günlük hayata uyarlama düzeyleri üzerine bir araştırma. Yüksek lisans tezi. Gazi Üniversitesi, Eğitim Fakültesi, Ankara.

Ayvacı, A., Özsevgeç, T. ve Cerrah, L. (2004). Yıldırım kavramının farklı yaş grubundaki öğrencilerde gelişimi, G.Ü. Kastamonu Eğitim Dergisi, 12(2), 351-361.

Baker, C.,Wuest, J. and Stern, P.N. (1992). Methodslurring: The grounded theory/ phenomenologyexample. Journal of Advanced Nursing, 17, 1355-1360.

Bar, V. and Travis, A. S. (1991). Children's views concerning phase changes. Journal of Research in Science Teaching, 28, 363-382.

Başer, M. ve Çataloğlu, E. (2005). Kavram değişimi yöntemine dayalı öğretimin öğrencilerin ısı ve sıcaklık konusundaki yanlış kavramlarının giderilmesindeki etkisi, Hacettepe Üniversitesi Ĕ̆itim Fakültesi Dergisi, 29, 43-52.

Başkale, H. (2016). Nitel araştırmalarda geçerlik, güvenirlik ve örneklem büyüklügü̈nün belirlenmesi. DEUHFED, 9(1), 23-28.

Bayrakçı, M. (2007). İlköğretim 5. sinıf öğrencilerinin "maddenin değişimi ve tanınması" ünitesindeki temel kavramlar anlama seviyeleri ve oluşan kavram yanilglarmnn tespiti. Yüksek lisans tezi. Atatürk Üniversitesi, Fen Bilimleri Enstitüsü, Erzurum.

Bayram, A. (2010). Probleme dayal öğrenme yönteminin ilköğretim 5. sinnf öğrencilerinin fen ve teknoloji dersi "ssi ve sicaklk" konusunda sahip oldukları kavram yanilgilarm gidermede etkisi. Yüksek lisans tezi. Selçuk Üniversitesi Eğitim Bilimleri Enstitüsü, Konya.

Boz, Y. (2006). Turkishpupils' conceptions of theparticulatenature of matter. Journal of ScienceEducationandTechnology, 15(2), 203-213.

Caleon, I. ve Subramaniam, R. (2010). Do students know what they know and what they don't know? Using a four-tier diagnostic test to assess the nature of students' alternative conceptions. Research in Science Education, 40, 313-337.

Carlton, K. (2000). Teaching about heat and temperature. Teaching Physics, 35(2), 101105.

Creswell, J., W. (2007). Qualitative inquiry and research design: choosing among five traditions. California: Sage.

Çakır, Y. (2005). Ilköğretim öğrencilerinin sahip oldukları kavram yanılgılarmmn belirlenmesi. Yüksek lisans tezi. Marmara Üniversitesi Eğitim Bilimleri Enstitüsü, İstanbul. 
De Berg, K.C. (2008). The concepts of heat and temperature: the problem of determining the content for the construction of an historica case study which is sensitiveto nature of science issues and teaching learning issues. Science and $E d u-$ cation, 17, 75-114.

Demirci, M. P. ve Sarıkaya, M. (2004). Sınıf Öğretmeni Adaylarının Isı ve Sıcaklık Konusundaki Kavram Yanılgıları ve Yanılgıların Giderilmesinde Yapısalcı Kuramin Etkisi. XIII. Ulusal Ĕ̈itim Bilimleri Kurultayı, 6-9 Temmuz 2004 İnönü Üniversitesi, Eğitim Fakültesi, Malatya.

Demircioğlu, H. (2003). Sinfföğretmen adaylarının kimya kavramlarmı anlama düzeyleri ve karşlaş̧lan yanllgllar. Yüksek lisans tezi. Karadeniz Teknik Üniversitesi Fen Bilimleri Enstitüsü, Trabzon.

Demircioğlu, H., Vural, S. ve Demircioğlu, G. (2014).Yapılandırmacı yaklaşımın üstün yetenekli öğrencilerin anlamaları üzerine etkisi: 'Erime-Donma'.Dicle Üniversitesi Ziya Gökalp Eğitim Fakültesi Dergisi, 22, 31-50.

Erdem, E., Yılmaz, A., ve Gücüm, B. (2004). Öğrencilerin madde konusunu anlama düzeyleri, kavram yanılgıları, fen bilgisine karşı tutumları ve mantıksal düşünme düzeylerinin araştırılması. Hacettepe Üniversitesi Eğitim Fakültesi Dergisi, 27, 74-82.

Erkaçan, İ., Moğol, S. ve Ünsal, Y. (2012). Çoklu zekâ kuramının lise 1. sınıf öğrencilerinin ıs1-sıcaklık, genleşme ve sıkıştırlabilirlik konularındaki akademik başarılarına ve öğrenmenin kalıcllğına etkisi. Türk Fen Eğitimi Dergisi, 9(2), 6578.

Gökulu, A. (2015). Sınıf öğretmeni adaylarının "1sı, sıcaklık, hal değişimi" kavramlarını anlama seviyelerine ilişkin bir çalısma. Mersin Üniversitesi Eğitim Fakültesi Dergisi, 11(2), 301-314.

Gürdal Kazancıŏlu, H. (2008). İlköğretim 5. smiffen ve teknoloji dersi, maddenin değişimi ve tanımması ünitesinde öğrencilerde oluşan kavram yanılgılarmın tespitinde iki aşamalı sorularn kullanulabilirliği üzerine bir araştırma. Yüksek lisans tezi. Celal Bayar Üniversitesi Sosyal Bilimler Enstitüsü, Manisa.

Gürses, A., Doğar, Ç., Yalçın, M. ve Canpolat, N. (2002). Kavramsal değişim yaklaşımunı öğrencilerin gazlar konusunu anlamalarına etkisi. Journal of Research in ScienceTeaching, 33(4), 407-431.

Griffths, A. K., and Preston, K. R. (1992). Grade-12 students' misconceptions relating to fundamental characteristics of atoms and molecules. Journal of Research in Science Teachig, 29(6), 611-628. 
Gönen, S. ve Akgün, A. (2005). Bilgi eksiklikleri ve kavram yanılgılarının tespiti ve giderilmesinde, çalışma yaprakları ve sınıf içi tartışma yönteminin uygulanabilirliği üzerine bir araştırma. Elektronik Sosyal Bilimler Dergisi, 4(13), 99111.

Hacımustafaoğlu, M. (2015). Ortaokul 8. sinıf ögrrencilerinin "Maddenin Halleri ve Isı" ünitesinde kavramsal değişim sağlamalarmda farkl kavramsal değişim yöntem ve tekniklerle zenginleștirilmiş rehber materyallerin etkisi. Yüksek lisans tezi. Giresun Üniversitesi/ Fen Bilimleri Enstitüsü, Giresun.

Jara-Guerrero, S. (1993). Misconceptions on heat and temperature. In TheProceedings of the Third International Seminar on MisconceptionsandEducationalStrategies in Science and Mathematics. Ithaca: Misconceptions Trust.

Jones, M. G., Carter, G. and Rua, M. J. (2000). Exploring the development of conceptual change cologies: communities of concepts related to convection and heat. Journal of Research in ScienceTeaching, 37, 139-159.

Kaplan, D. (2007). Maddedeki değişim ve enerji ünitesindeki kavram yanılgılarının tespiti ve bilgisayar destekli öğretim yöntemiyle giderilmesi. Yüksek lisans tezi. Marmara Üniversitesi Eğitim Bilimleri Enstitüsü, İstanbul.

Karakuyu, H., Uzunkavak, M., Tortop, H. S., Bezir, N. Ç., ve Özek, N. (2006). Sandıklı çevresi lise ve dengi okul öğrencilerinin ısı ve sıcaklık ile ilgili kavram yanılgilarının belirlenmesi. Afyon Kocatepe Eğitim Bilimleri Dergisi, 8(1), 149-162.

Keser, A. (2007). Afyonkarahisar il merkezindeki 9. sinfföğrencilerinin ısı ve sıcaklik konusundaki kavram yanllgılarn. Yüksek lisans tezi. Kocatepe Üniversitesi Fen bilimleri Enstitüsü, Afyonkarahisar.

Kesidou, S ve Duit, R. (1993). Student' conceptions of thesecondlaw of thermodynamics- An interpretative study. Journal of Research in ScienceTeaching, 30, 85106.

Kırıkkaya, B. ve Güllü, D. (2008). İlköğretim beşinci sınıf öğrencilerinin ısı - sıcaklık ve buharlaşma - kaynama konularındaki kavram yanılgıları, İlköğretim Online, $7(1), 15-27$.

Kızılaslan, A. (2016). İköğretim 8. sinıf görme engelli ö̆rencilere "maddenin halleri ve ısı" ünitesi ile ilgili kavramlarm öğretimi. Doktora tezi. Erzurum Üniversitesi, Eğitim Bilimleri Enstitüsü, Erzurum.

Kocakülah M. S. ve Kocakülah, A. (2002). Ortä̈gretim Öğrencilerinin Isı ve Sıcaklık ile Illgili Kavramsal Yapıları. V. Ulusal Fen Bilimleri ve Matematik Eğitimi Kongresi, 16-18 https://docplayer.biz.tr/36849768-Ortaogretim-ogrencilerinin-isi-ve-sicaklik-ile-ilgili-kavramsal-yapilari.html adresinden 22/12/2017 tarihinde erişilmiştir. 
Lewis, E. L. and Linn, M. C. (1994). Heatenergyandtemperatureconcepts of adolescents, adults, andexperts: Implicationsforcurricularimprovements. Journal of Research in ScienceTeaching, 31, 657-677.

Merriam, S. B. (2013). Nitel araştırma desen ve uygulama için bir rehber. Ankara: Nobel

Miles, M. B. and Huberman, A. M. (2015). Nitel veri analizi. Ankara: Pegem Akademi. Ongun, E. (2006). Üniversite öğrencilerin ısı ve sıcaklık konusundaki kavram yanılgılar ile motivasyon ve bilişsel stilleri arasındaki ilişki. Abant İzzet Baysal Üniversitesi Sosyal Bilimler Enstitüsü, Bolu.

Osborne R. J. and Cosgrove, M. M. (1983). Children'sconceptions of changes of thestate of thewater. Journal of Research in ScienceTeaching, 20, 825-838.

Osborne, R. J. and Gilbert, J. K. (1980). A Technique for exploring students' views of world. Physics Education, 15, 376-37.

Othman, J.,Treagust, D. and Chandrasegaron, A. L. (2007). An Investigation into the relationship between student's conceptions of the particulate nature of matter and their understanding of chemical bonding. International Journal of Science Education, 1, 1-20.

Özalp, D. (2008). Illköğretim ve ortäğretim öğrencilerinin maddenin tanecikli yapısı konusundaki kavram yanilglarmmn ontoloji temelinde belirlenmesi. Yüksek lisans tezi, Marmara Üniversitesi Eğitim Bilimleri Enstitüsü, İstanbul.

Özmen, H. ve Kenan, O. (2007). Determination of theTurkish primary students' views about the particulate nature of matter. InAsia-Pacific Forum on Science Learning and Teaching, 8(1), 1-15.

Paik S-H., Kim H-N., Cho B-K and Park J-W. (2004). K-8th grade Korean students' conceptions of changes of state" and "conditions for changes of state. International Journal of ScienceEducation, 26(2), 207-224.

Patton, M., Q. (2018). Qualitative research evulation methods. California: Sage

Rose, P.,Beeby, J. and Parker, D. (1995). Academicrigour in the lived experience of researchersusing phenomenological methods in nursing. Journal of Advanced Nursing, 21, 1123-1129.

Saka A. ve Ayas, A. (2002). Öğrencilerin mikrop kavramı ile ilgili düşüncelerinin yaşlara göre değişimi, M.Ü. Atatürk Eğitim Fakültesi Eğitim Bilimleri Dergisi, 16, 139-148.

Sarı, A. (2014). Kavram haritası ve bilgisayar destekli öğretimin 7. smnföğrencilerinin madde konusundaki kavram yannlgılarma etkisinin ontolojik açıdan incelenmesi. Doktora tezi. Marmara Üniversitesi Eğitim Bilimleri Enstitüsü, İstanbul. 
Sarı Ay, Ö. (2011). Illköğretim 8. sinıffen ve teknoloji dersi 'maddenin halleri ve ısı' ünitesinde belirlenen kauram yanılgilarının giderilmesinde kauramsal değişim metinlerinin kullanımının etkisi ve öğrenci görüşleri. Yüksek lisans tezi. Hacettepe Üniversitesi Sosyal Bilimler Enstitüsü, Ankara.

Sarıkaya, Ş. (2001). Orta öğretim öğrencilerinin "maddenin oluşumu" ünitesine yönelik kavram yanılglarının belirlenmesi (Balkesir örneği). Yüksek lisans tezi, Balıkesir Üniversitesi Fen Bilimleri Enstitüsü, Balıkesir.

Seidman, I. (2006). Interviewing as qualitativeresearch. New York andLondan: TeachersCollegePress. $\quad$ https://books.google.com.tr/books?hl=tr\&lr=\&id=pk1RmqY15QC\&oi=fnd\&pg=PR9\&dq=seidman+2006\&ots=4qc-UUTKE)\&sig=by5iqoqt7E]T1HkWA7xAgUke6Y\&redir esc=y\# $\mathrm{v}=$ onepage\&q=seidman\%202006\&f=false adresinden 15/09/2020 tarihinde erişilmiştir.

Sopandi, W.,Latip, A. and Sujana, A. (2017). Prospectiveprimaryschoolteachers' understanding on states of matterandtheirchanges. Journal of Physics: Conference Series, 812, 1-8.

Stavy, M. (1990). Children'sexperts: Implications for curricular improvements. Journal of Research in ScienceTeaching, 31, 657-677.

Şendur, G. (2004). Buharlaşma, kaynama konularnndaki kavram yamlgilarmin önlenmesi için Ausubel' in anlamlı ögretme yönteminin uygulanması. Yüksek lisans tezi. Dokuz Eylül Üniversitesi, Eğitim Bilimleri Enstitüsü, İzmir.

Şendur, G., Toprak, M. ve Pekmez, E., S. (2008). Buharlaşma ve kaynama konularındaki kavram yanılgılarının önlenmesinde analoji yönteminin etkisi. Ege Ĕ̆itim Dergisi, 2(9), 37-58.

Şenocak, E., Dilber, R., Sözbilir, M. ve Taşkesenligil, Y.(2003). İlköğretim öğrencilerinin $1 s ı$ ve sıcaklık konuların kavrama düzeyleri üzerine bir araştırma. $P a-$ mukkale Üniversitesi Ĕ̆itim Fakültesi Dergisi, 13, 199-210.

Taşlıdere, E., Korur, F. ve Eryılmaz, A. (2012) Kavram yanılgılarının üç-aşamalı sorularla farklı bir şekilde değerlendirilmesi, X. Ulusal Fen Bilimleri ve Matematik Eğitimi Kongresinde sunulmuş bildiri, Niğde.

Türkoğuz, S. ve Yankayış, K. (2015). Isı ve sıcaklık hakkındaki kavram yanılgılarının günlük yaşama etkileri üzerine öğretmen görüşleri. Bayburt Üniversitesi eğitim Fakültesi Dergisi, 10(2), 498-515.

Uzoğlu, M. ve Gürbüz, F. (2013). Fen ve Teknoloji öğretmen adaylarının ısı ve sıcaklık konusundaki kavram yanılgılarının belirlenmesinde öğrenme amaçlı mektup yazma aktivitesinin kullanılmass. International Journal of SocialScience, $6(4), 501-514$. 
Yıldırım, N. ve Konur, K., B. (2014). Fen bilgisi öğretmen adaylarının kimya kavramların günlük hayatla ilişkilendirebilmelerine yönelik gelişimsel bir araştirma. TheJournal of AcademicSocialScienceStudies, 30, 305-323.

Yıldırım, A. ve Şimşek, H. (2013). Sosyal bilimlerde nitel araştırma yöntemleri. Ankara: Seçkin Yayınları.

\section{EK-1. “Isı ve Sicaklık Kavram Testi”}

S.1. Isı kavramını ve sıcaklık kavramını açılayınız.

S.2. Okuldaki koridorlar su ile yıkandıktan ya da paspasla silindikten sonra serinleme hissedilir. S.3. Bu serinleme hissi neden kaynaklanmaktadır?

S.4. Avucumuza bir parça buz alıp beklediğimizde bir süre sonra buz parçasının eriyerek suya dönüștüğünü görürüz. Bunun nedeni sizce ne olabilir?

S.5. Aşağıdaki grafikte naftalin, kükürt, bakır ve kurşunun erime sıcaklıkları verilmiştir.

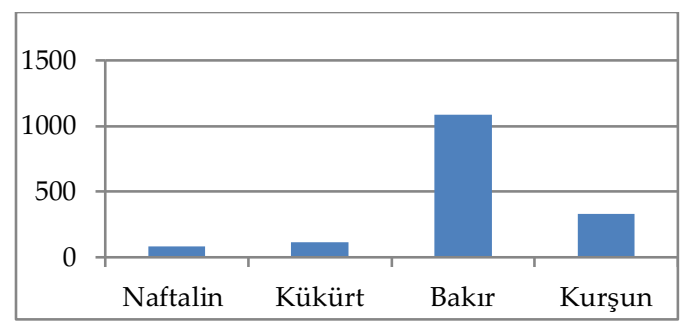

Grafiğe göre;

- Hangi maddenin donma sıcaklığı en yüksektir? Açklayınız.

- Hangi maddeyi eritmek en zordur? Açıklayını.

"Su $0^{\circ} \mathrm{C}$ de donarak buz haline geçer. Su donarken enerjisinin tamamın verdiğinden, 0 ${ }^{\circ} \mathrm{C}$ deki buzun ısısı yoktur." Bu ifadenin doğruluğu hakkında ne düşünüyorsunuz? Açıklayiniz.

\section{EK-2.“Maddenin Halleri Kavram Testi”}

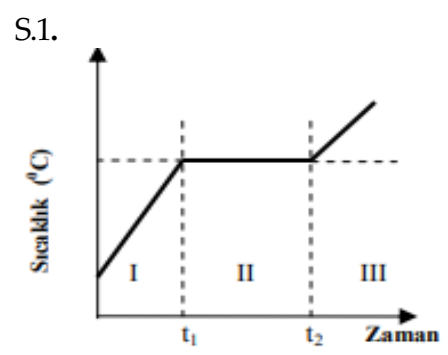


- Bu grafik ne olarak adlandırilır?

- I. bölgede ne gibi değişiklikler meydana gelir? Açıklayın?

- II. bölgede ne gibi değişiklikler meydana gelir? Açıllayın?

- IIII. bölgede ne gibi değişiklikler meydana gelir? Açıklayın?

S.2.Sıcak bir havada serinlemek için kutu içecek aldığınızı düşünün. Eve geldiğinizde içeceğin soğuması için kısa bir süre buzluğa içeceği koydunuz. Buzluktan alıp içmeye başladınız. Bir süre sonra kutu içeceğin dış yüzeyinde su damlaları olduğunu görürsünüz. Sizce bu durumun nedeni nedir?

S.3.

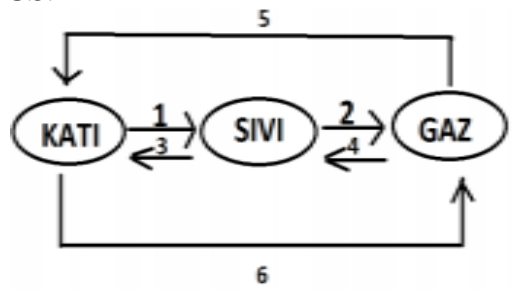

Yukarıda yer alan şekli göz önüne alarak aşağıdaki soruları cevaplayınız.

I.Katı, sıvı ve gazlar ile ilgili olarak numaralandırılmış bölümlerin ne olduğunu yazınız.

II. Numaralandırılmış olaylarda 1sı, sıcaklık, kütle, tanecik miktarı ve tanecik hareketinde değişme meydana gelir mi? Açıklayınız.

S.4. Maddenin düzensiz halden düzenli hale geçtiği durumlara örnekler veriniz. Isı ve sıcaklıkla bu olayların bir ilişkisi var mıdır? Açklayınız.

\section{Kaynakça Bilgisi / Citation Information}

Ural, E. ve Başaran Uğur, A. R. (2021). Fen Bilgisi öğretmen adaylarının isı-sıcaklık ve maddenin halleri konularına ilişkin kavram yanılgıları arasındaki ilişkinin incelenmesi. OPUS-Uluslararası Toplum Araştırmaları Dergisi, 18(40), 2221-2257. DOI: 10.26466/opus.868034. 